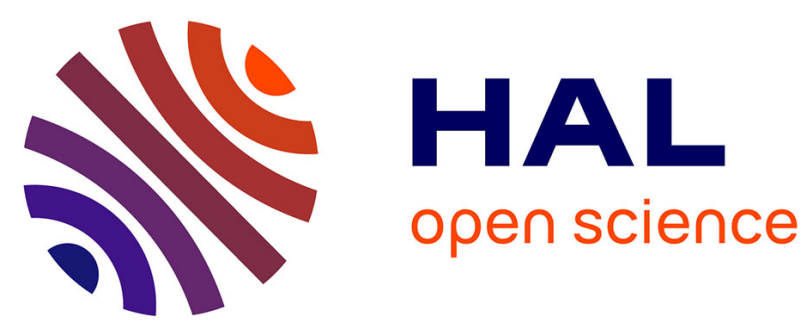

\title{
Source Rocks and Related Petroleum System of Chelif Basin, (Western Tellian Domain, Algeria)
}

Mohamed Arab, Rabah Bracène, François Roure, Réda Samy Zazoun, Yamina Mahdjoub, Rabi Badji

\section{- To cite this version:}

Mohamed Arab, Rabah Bracène, François Roure, Réda Samy Zazoun, Yamina Mahdjoub, et al.. Source Rocks and Related Petroleum System of Chelif Basin, (Western Tellian Domain, Algeria). Marine and Petroleum Geology, 2015, 64, pp.363-385. 10.1016/j.marpetgeo.2015.03.017 . hal-01174862

\section{HAL Id: hal-01174862 \\ https://hal.science/hal-01174862}

Submitted on $10 \mathrm{Jul} 2015$

HAL is a multi-disciplinary open access archive for the deposit and dissemination of scientific research documents, whether they are published or not. The documents may come from teaching and research institutions in France or abroad, or from public or private research centers.
L'archive ouverte pluridisciplinaire HAL, est destinée au dépôt et à la diffusion de documents scientifiques de niveau recherche, publiés ou non, émanant des établissements d'enseignement et de recherche français ou étrangers, des laboratoires publics ou privés. 
4 Mohamed Arab $^{a, b}$, Rabah Bracène ${ }^{a}$, François Roure ${ }^{c, d}$, Réda Samy Zazoun ${ }^{e, ~ *}$, 5 6

7 ( $\left.{ }^{a}\right)$ Sonatrach-Division Exploration, Avenue du $1^{\text {er }}$ Novembre Bat 'C' BP 68M, 8 Boumerdès, Algeria.

9 E-mail adress : Mohamed.arab@ep.sonatrach.dz

$10 \quad\left({ }^{b}\right)$ Faculté des Sciences de la Terre, de la Géographie et de l'Aménagement du 11 Territoire, USTHB, BP 32, Bab Ez Zouar, Algiers 16111, Algeria.

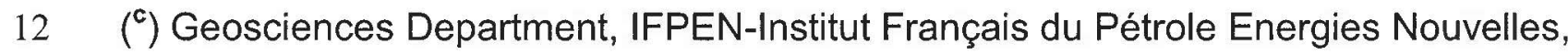
13 Rueil Malmaison, France.

14 ( ${ }^{\text {d }) ~ T e c t o n i c ~ G r o u p, ~ U t r e c h t ~ U n i v e r s i t y, ~ t h e ~ N e t h e r l a n d s . ~}$

$15\left({ }^{e}{ }^{*}\right)$ Corresponding author: Sonatrach-Division Technologies et Développement, 16 Avenue du 1er Novembre, Boumerdès, Algeria.

17 E-mail adress: redasamy.zazoun@ep.sonatrach.dz (R. S. Zazoun) 


\section{Introduction}

27 The study area lies in the external zone of the Rif-Tell or Maghrebides fold-and-thrust 28 belt, the southernmost segment of the Alpine orogeny (Durand-Delga et al., 1980; 29 Bracene and Frizon de Lamotte, 2002; Roure et al., 2012), which trends roughly 30 east-west in northern Algeria (Fig. 1). The Chelif Basin is a dominantly Neogene 31 trans-tensional basin located within the Northern Algerian foothills, southwest of the 32 Kabylian ridge, which constitutes the surface expression of the paleo-suture between 33 (1) exotic terranes of European affinities (Kabylides Crystalline Massifs and 34 associated Mesozoic to Eocene sedimentary cover), and (2) the Tellian allochthon, 35 made up of Mesozoic basinal units derived from the former passive margin of North 36 Africa (Benaouali-Mebarek et al., 2006, and references therein). The Neogene 37 sedimentary infill of the Chelif Basin rests on top of the allochthonous basinal 38 Mesozoic to Paleogene carbonates and sandstones units of the southern Tellian 39 allochthon.

40 Since the discovery of the small oil fields of Ain zeft and Tliouanet in the Chelif Basin 41 in 1872 , followed by Oued Gueterini in 1948 in the Hodna area, Northern Algeria 42 constitutes an interesting zone for explorationists. Besides, many oil and gas shows 43 exist either in the Saharan Atlas, south of the Alpine thrust front, or within the Tellian 44 domain itself. The potential plays relate to Miocene compressional structures in the 45 partially inverted foreland, in subthrust units and intra-mountain basins, as well as in 46 Triassic to Jurassic extensional structures still preserved in the foreland autochthon.

47 The aim of this paper is to (1) identify potential source rocks in the Neogene Chelif 48 Basin, in its allochthonous Tellian substratum, as well as in the underlying 49 underthrust foreland, (2) locate the hydrocarbon kitchens and study the HC potential 50 of these formations, (3) establish oil to source rock correlations in order to trace the 
51 origin of the oils in the fields, (4) assess the timing of $\mathrm{HC}$ migration and trapping, and 52 (5) define the main petroleum systems.

\section{$54 \quad 2 . \quad$ Geological setting}

55 The intra-mountain Chelif Basin (Perrodon, 1957) is located in the western part of the 56 Tellian Atlas It is elongated in the east-west direction, with steep border faults 57 delineating individual pull-apart basins filled by Miocene to Pliocene series (Fig. 1). 58 Its structure developed following the last phases of the Alpine orogeny (Aifa et al., 59 1992). For instance, during the Neogene, the plate boundary between the Western 60 Mediterranean and the Kabylides in the north and Africa in the south was a 61 dominantly transform boundary, slab detachment and strike-slip faulting accounting 62 for the lateral escape of the Gibraltar arc and Alboran block towards the west and 63 Tyrrhenian-Calabrian arc towards the east (Hsü, 1971; Olivier, 1984; Thomas, 1985; 64 Carminati et al., 1998; Spakman and Wortel, 2004, and references therein). Due to 65 strain partitioning, numerous episodes of transpression and transtension were then 66 recorded in the Chelif area, both in the Tellian allochthon and underlying underthrust 67 foreland. The tectonic studies show that the present deformation is mainly 68 compressive with a NNW-SSE direction of shortening (Philip and Thomas, 1977; 69 Meghraoui, 1982; Philip and Meghraoui, 1983; Meghraoui, 1988; Meghraoui and 70 Doumaz, 1996; Meghraoui et al., 1996; Boudiaf et al., 1998; Domzig et al., 2006; 71 Yelles-Chaouche et al., 2006; Guemache, 2010). According to Rebaï (1993), the 72 present state of regional stresses suggests that the Maghreb is subjects to a N-S 73 compression and acts as an indenter in its central Algerian part, the western and 74 eastern parts (Morocco and Tunisia) being allowed to experience a lateral escape 75 (Piqué et al., 1998a \& b). Furthermore, based on paleomagnetic measurements, the 
76 relative convergence motion between the Africa and Eurasia plates could be

77 interpreted as a transpressional tectonic deformation model with block rotations along 78 the Algerian continental margin (Derder et al., 2013).

\section{2.1. Geodynamic evolution and tectonic agenda}

81 After the opening of the Tethys Ocean and coeval development of the northern 82 passive margin of Africa during the Triassic and Liassic, the rotation of the African 83 plate as compared to Eurasia induced since the Upper Jurassic a slow convergence 84 between the two plates. This led to a progressive closure of the former ocean, and to 85 the formation of the circum-Mediterranean Alpine mountains (Thomas, 1985). During 86 the Late Cretaceous until the Eocene, foreland inversions developed in the former rift 87 basins of the Saharan Atlas, due to a good coupling between the plate boundary and 88 the African lithosphere, at a time when the oceanic domain was not yet fully 89 subducted (Frizon de Lamotte et al., 2006; Bracène and Frizon de Lamotte, 2002; 90 Roure et al., 2012).

91 Surprisingly enough, the Tellian allochthon is made up of Upper Cretaceous to 92 Eocene basinal units derived from the distal portion of the former passive margin of 93 North Africa, with a basal decollement located in Triassic evaporites, with no 94 evidence of Lower Cretaceous nor Jurassic series in between. The best interpretation 95 here is to assume, as what has already been described for the Eastern Algerian and 96 Tunisian Tell, that salt canopies made up of Triassic series were already 97 interstratified within the Cretaceous series of the passive margin (Vila et al., 1993; 98 Masrouhi and Koyi, 2012, and references therein), thus allowing a localisation of the 99 main decollement along these interfaces during the subsequent episodes of thrusting. 100 Deep water turbidites of the Oligocene Numidian series were actually deposited in 
101 the distal portion of the African margin and on top of the southward propagating 102 Tellian tectonic wedge.

103 The paroxysmal phase of thin-skinned deformation resulted in the overthrusting in the 104 Tellian allochthon during the Lower Miocene. As a result, Langhian series are 105 currently located in three distinct tectonic positions in the vicinity of the Chelif Basin water turbidites rest directly on top of Upper Cretaceous blackshales in Tiaret, (2) in the footwall of the Tellian allochthon, where the Lower Miocene series still constitute a potential seal for the Mesozoic reservoirs of the subthrust prospects, and (3) on top 110 of the Tellian allochthon, in a piggyback position.

111 After the final emplacement of the Tellian allochthon on top of its foreland domain, an 112 episode of trans-tension occurred along the plate boundary during the Tortonian and 113 Messinian, accounting for the formation of thrust-top pull-apart basins in the Chelif 114 area (Ghazli, 2001; Roure, 2008; Roure et al., 2012), in a similar way as what has 115 been described for the Vienna Basin at the junction between the Alps and the 116 Carpathians (Sauer et al., 1992; Seifert, 1996), or in the Gulf of Paria between the 117 Serrania del Interior in Eastern Venezuela in the west, and Trinidad in the east 118 (Lingrey, 2007).

119 Since the Pliocene, there is again a good coupling between the plate boundary and 120 the African foreland, accounting for the transpressional inversion of former normal 121 faults inherited from the Tethyan rifting in the underthrust African foreland. This new 122 compressional episode has resulted in the formation of subthrust anticlines involving 123 the Mesozoic parautochthonous series and in the refolding of the sole thrust of the 124 overlying Tellian allochthon beneath the Chelif Basin, in a similar way as in the 125 Tempa Rossa and Monte Alpi fields of the Southern Apennines and other nappes 
126 anticlines described in Northern Sicily (Casero et al., 1991; Roure et al., 2012), in the

eastern part of the Algerian Tell near Constantine (Vila et al., 1994), as well as in the tectonic windows of the Bibans and Ouarsenis Mountains (Mattauer, 1958), where the lower plate is currently exposed to the surface due to the large amount of tectonic uplift and erosion.

\section{2.2. Neogene sedimentary infill of the Chelif Basin}

133 Due to the complex tectonic evolution of the Chelif Basin, its Neogene sedimentary 134 infill can be subdivided into 3 distinct tectonostratigraphic assemblages (Neurdin135 Trescartes, 1992 and 1995; Fig. 3):

136 At the base, the marine Lower Miocene megasequence (MSI) was still deposited 137 during a compressional episode, in a piggyback position on top of the still moving 138 Tellian. During the Lower Miocene, the sedimentary deposits preserved on top of the 139 Tellian units, and especially in the western sub-basin of the Chelif, record the 140 influence of arc-related alkaline and calc-alkaline volcanism.

141 The thicker Tortonian-Messinian megasequence (MSII) was deposited during the 142 formation of the trust-top pull-apart basin, during the episode of transtension. It still 143 comprises dominantly marine siliciclastic deposits at the base, grading into marl, 144 continental siliciclastic deposits and intense volcanism, like cinerites, that are considered as a chronologic marker at the base of Messinian (Kieken, 1974 and 1975).

147 The Plio-Quaternary sequence (MS III) was deposited during the reactivation and 148 inversion of the border faults of the Chelif Basin, coeval with the formation of subthrust structural closures in the underthrust foreland. It is made up of shallow marine (Algae limestone) and continental siliclastic deposits. 
152

\section{Results}

\subsection{Source rocks characterization}

At the scale of the Circum-Mediterranean basins and thrust-belts, numerous stratigraphic intervals have been recognized since a long time as potential source rocks for hydrocarbons. This is the case for Upper Triassic bituminous limestones in Sicily and the Adriatic domain (Southern Alps, Dinarides and Albanides; Ziegler and Roure, 1996, and references therein), Liassic blackshale in the Saharan Atlas in Algeria (Vially et al., 1994), in the lonian zone in the Albanides, in Epirus in the 160 Hellenides (Karakitzios, 2013, and references therein), Cenomanian-Turonian euxinic 161 facies in the Apennines, Eocene blackshale in the Eastern Tell in Algeria, Oligocene 162 Numidian flysch in Tunisia and Sicily, as well as Messinian series.

163 In the Chelif area, only the Cretaceous and Cenozoic rocks of the Tellian allochthon 164 and Neogene pull-apart basin have been investigated here, due to the current lack of 165 deep well that would be required to document potential source rocks in the lower 166 plate (underthrust foreland).

\subsubsection{Upper Cretaceous (Cenomanian to Campanian)}

As is most of North Algeria, Upper Cretaceous series of the Tellian allochthon cropping out in the vicinity of the Chelif Basin are locally preserved around the main Neogene depocenters, either is the form of well stratified Campanian outcrops, or as hard blocks of Cenomanian limestones reworked in the shaley matrix of tectonic mélanges along the sole thrust of the allochthon (Fig. 2). These Upper Cretaceous series have been sampled in outcrops of the northern and southern borders (Fig. 1). The facies is composed of grey to black shales and marls. Their organic richness is 
mean to good. TOC varies from 1.5 to $7 \%$ (Roure et al., 2006). TOC values varies from 0.56 to $3 \%$ Relizane and Beni Chograne mountain, near Tliouant field the southeast, in the Dahra Mountains it ranges from 0.9 to $8.2 \%$. The present day maturity shows a frozen oil window in the basin borders (outcrops) and instead a gas window in wells drilled in the central part of the Neogene basin (Fig. 3). Some outcrop's samples display high residual potential with HI varying from102 to $480 \mathrm{mg} / \mathrm{g}$ TOC (Fig. 4 and Tab. 1), they are in oil window (Tmax $\left.=438-443^{\circ} \mathrm{C}\right)$, the lower $\mathrm{HI}$ (5- $12 \mathrm{mg} \mathrm{Hc} / \mathrm{TOC}$ ) indicate a gas window, the Tmax is higher (574- $\left.599^{\circ} \mathrm{C}\right)(\mathrm{Tab} .1)$.

\subsubsection{Oligocene Numidian series}

The Oligocene Numidian flysch crops out also in the Tellian allochthon on both sides of the Neogene depocenters, but it may be entirely lacking beneath the whole basin as due to the geometry of the Miocene normal faults. It consists of grey to black marls (Fig. 3) deposited in a deep water environment. Its thickness reaches up to 500 $\mathrm{m}$. TOC varies from 2 to $4 \%$, which gives an equivalent of 10 to $30 \%$ in carbonate composition. The HI/OI diagram (Fig. 5) shows a type-Ill kerogen. However, the optical observation reveals amorphous sapropelic organic matter. This low potential at lower maturity indicates a poor preservation of the organic matter due to oxidation (Fig. 5). Whole samples display low to fair TOC, ranging from 0.4 to $0.9 \%$ and low maturity. In the central part of the basin, the organic matter reached the oil window at about $2100 \mathrm{~m}$ and a wet gas window at about $3,500 \mathrm{~m}$. The environment of deposition, mainly controlled by the geometry of the Maghrebides-Apenninic flexural basin, was probably not in direct communication with the Atlantic Ocean where upwelling streams could have occurred and could have renewed the anoxic zones with minerals that are necessary for the proliferation of the organic matter. 


\subsubsection{Lower to Middle Miocene}

Their thick series of blue marls are characterized by a weakness of organic matter; the TOC is generally lower than $0.5 \%$ (Figs. 6 and 7), this is due mainly to a dilution which is related to a high sedimentation rates $(1000 / m y)$. Nevertheless, they contain thin (decimeter-thick) layers which are limited in space with the TOCs ranging from 0.8 to $1 \%$, like in El-Biod and Ain Zeft area (Fig. 6 and 7). The organic matter is from type II marine with probably inclusion of terrestrial material (Fig. 8), regarding the proximity of the land to the deep basin. Although the lower potential could be the result of the thermal maturation process (Figs. 5 and 8), the high oxygen index $(\mathrm{IO}=$ 200- 400mg CO2/g COT) (Figs. 5 and 7) traduces an oxidation and thus a bad preservation of the organic matter (Fig. 8). In terms of maturity the deepest layers are in gas window (Figs. 5 and 8), in the central part of the basin (El-Biod, Nador, Akboub and Belkheir) and in oil window in shallower areas, such as Noisy and Fornaka.

\section{3.1.4. Upper Miocene series}

217 The Upper Miocene series have been sampled in the northeastern (El-Biod and Aïn 218 Zeft) and southwestern parts (Belkhir and Fornaka) of the basin (Fig. 1) at depths 219 varying from 500 to $750 \mathrm{~m}$. Apart of the Tripoli member of the Messinian where TOC 220 values can reach up to $10 \%$ or more, he average TOC values of other Miocene 221 intervals range from less than $0.5 \%$ to $1 \%$ (Fig. 5).

222 The majority of the samples in Aïn Zeft (Fig. 7), Akboub and Hellil areas display high 223 oxygen and lower hydrogen proportion in the organic matter (Fig. 5). The hydrogen 224 index is around $100 \mathrm{mg} \mathrm{HC} / \mathrm{g}$ TOC (Fig.5). In the El Biod area, the basal part of the 225 Upper Miocene presents a fair quality of organic matter (fig. 4 and 7). There, the 
226 Hydrogen index $(\mathrm{HI})$ ranges from 100 to $150 \mathrm{mg} \mathrm{HC} / \mathrm{g} \mathrm{TOC}$, the sample actually 227 recording a maturity grade at the beginning of oil window (Figs. 6 and 7). Besides, close to the northern border of the basin near Ain Zeft and Dahra Mountain outcrop samples have been analysed, they show a good organic richness, with a TOC of 1.18- $2.31 \%$ (Fig. 4 and Tab. 1). However, even though the thermal indicators Tmax $\left(<430{ }^{\circ} \mathrm{C}\right)$ and $\left.\mathrm{TAl}=1.5\right)(\mathrm{Tab} .1)$ traduces an immaturity of the organic matter, only two samples display fair to excellent potential ( $\mathrm{HI}=211$ and $566 \mathrm{mg} \mathrm{hc} / \mathrm{g} \mathrm{TOC})$. The rest of the samples are characterized by low hydrogen indices, this is due probably to a bad preservation or oxidation of the organic matter. Nevertheless, the oil shows and the Ain Zeft accumulation is an indication that there is an efficient kitchen zone in the vicinity of the area, the lack of the reliable samples does not allow establishing a thermal maturity map.

\subsection{Oil-source rocks correlations}

The normalized percentage compositions of the aliphatic, aromatic and NSO fractions of each sample of rock extracts and oils are plotted in a ternary diagram (Fig. 9). According to Tissot and Welte (1984), the grey area in the figure represents typical conventional petroleum composition. The samples present a lower proportion of aromatics hydrocarbons ( $\mathrm{HCA}$ ) and polar products (NSO) and high saturated hydrocarbons (HCS) (Fig. 9).

The graph PR/nC17 - PH/nC18 (Lumbach, 1975, in Chaouche, 1992) is used for defining the maturity and the type of organic matter of the source rock which has generated oils and extracts that are analyzed by chromatography in the framework of the present study and internal unpublished works of Sonatrach. The extract samples (at 1911 and 1936 m depth) from Hellil area (well W9) are classified in a type II zone 
251 after the graph and humic type zone for the third sample from $1584 \mathrm{~m}$ (Fig. 9). At El252 Biod well the diagram shows a type-Il kerogen and lower maturity as compared to 253 Akboub oils in the western area (Fig. 9).

254 An oil sample issued from Ain Zeft field (well W3) and a hydrocarbon extract of 255 Messinian marls (outcrops) have been analysed with gas chromatography and the 256 chromatograms of $\mathrm{C} 14+$ saturates are compared for a correlation need.The 257 Messinian extract is characterized by a predominance of even number components 258 and a low Pr/Ph fraction (0.5) (Fig. 10), this is an indication of a source rock that has 259 been deposited in a highly reduced evaporitic environment. Besides, as indicated 260 above, the samples are totally immature, C21-C35 being still present in high 261 proportion. The Ain Zeft oil sample displays the same distribution with also a low $262 \mathrm{Pr} / \mathrm{Ph}$ fraction (0.16) (Fig. 10). Moreover, the sulphur content in the present oil is 263 higher than $2 \%$, meaning that this oil was most probably generated from a type-IIS 264 organic matter. The chromatogram of Messinian extract (shows a high concentration 265 of biomarkers (Fig. 11a). Although the oil sample is slightly mature than the extract, 266 the two samples seems to be similar. The absence of gas spectrometry data (GCMS) 267 could not allow a complete correlation.

268 The oils from Tliouanet field are very mature because they contain a higher 269 proportion of C14-C21 components (Fig. 11c), the regular decreasing of the pick 45 heights, from $\mathrm{C} 19$ to $+\mathrm{C} 30$ component is an indication of a marine environment of 271 the organic matter, from which these oils have been generated (Fig. $11 \mathrm{c}$ ).The $\mathrm{Pr} / \mathrm{Ph}$ 272 fraction is 1.6; it is an indication of a highly reduced environment (Fig. $11 \mathrm{c}$ ). The 273 distribution of the extract component is the same as the one of the Tliouanet oil; the predomainance of $\mathrm{nC} 15-\mathrm{nC} 21$ components traduces the relatively higher maturity of the samples (Fig. 11 d). Furthermore, the stratigraphic position of the produced 
276 reservoir in Tliounat field (basal Tortonian sandstones) comparing to the Cretaceous

allochton source rock which belongs to the substratum of the Neogene Chelif basin, the migration pathways of this oil came from this Cretaceous level (Fig. 2). According to its geochemical signature, this oil is quite similar to the oils of the Oued Gueterini field farther east in the Hodna Basin, with strong affinities with extracts from Cretaceous source rocks. Because of the geometry of the Chelif Basin and their close association with the main border fault of the basin, these oils were probably generated from a deeper structural unit, with a dismigration from the subthrust parautochthous units or underthrust foreland, in a similar way as the Jurassicsourced oils found in the Neogene reservoirs of the Vienna Basin in Austria, which were actually generated in the lower plate, thus accounting for subsequent vertical migration across the sole thrust of the Tellian allochthon.

\subsection{Thermal modelling and hydrocarbon generation history}

\subsubsection{Geothermal boundary conditions}

291 1D thermal modelling in thrust belts remains a difficult task due to the spatial and 292 temporal changes operating in the lithosphere and crustal architecture from the onset 293 of rifting and passive margin development, which are usually characterized by a 294 relatively high thermal regime, until the orogenic paroxysm which is instead likely to 295 account for the development of a thicker crust, but also a thick lithospheric root, most 296 foreland flexural basins being instead characterized by relatively cold heat flows. 297 Alternatively, post-orogenic slab detachment and rise of an asthenospheric diapir 298 beneath the offshore Algerian basin may have restored temporally an elevated heat flow in the vicinity of the Chelif Basin at its Upper Miocene peak of subsidence. 
300 Another problem with 1D models is that they can hardly account for tectonic 301 duplication, the Tellian allochthon recording a completely different thermal evolution 302 as compared to the underthrust foreland until the Langhian, when the two domains 303 were ultimately superposed with only minor subsequent tectonic contraction.

304 In this paper, the aims of the 1D petroleum modelling with the Genex software was to 305 reconstruct the thermal, source rock maturation and petroleum generation in the 306 Neogene depocenter, with a focus on the evolution of the Neogene source rocks 307 from the post-nappe pull-apart basin. Further coupled 2D kinematic and petroleum 308 Thrustpack modelling has also been attempted in the past in the Chelif Basin to 309 address the thermal evolution of the lower plate and exploration risk of subthrust 310 prospects (Sassi et al., 2006), but these results will not be detailed here, because of 311 strong uncertainties when reconstructing the pre-Miocene thermal evolution of both 312 the Tellian allochthon and underthrust foreland.

313 In any case, the North Algerian Tellian Atlas presently displays a normal crust which 314 thickness ranges from 30 to $40 \mathrm{~km}$ (Marillier and Mueller, 1982; Thomas, 1985).

\subsubsection{Geothermal history}

317 Acccording to Louni-Hacini et al. (1995), Neogene volcanic rocks from the 318 northwestern coast of Algeria include calc-alkaline to shoshonitic andesites and 319 dacites (Sahel of Oran and M'Sirda areas) and alkaline basalts (Tafna valley). 320 Seventeen new ${ }^{40} \mathrm{~K}-{ }^{40} \mathrm{Ar}$ ages indicate that these volcanics were emplaced during 321 two distinct periods, from 11.7 to $7.2 \mathrm{Ma}$ and $4 \mathrm{Ma}$, respectively. All the andesites 322 and dacites were emplaced during the first period, and their trace element characteristics are typical of subduction- and/or collision-related magmas. During the 
324 Late Pliocene and Quaternary, the volcanic activity occurred in the Moroccan Middle 335 oceanic lithosphere of the offshore Algerian Basin. Takherist and Lesquer (1989).

In the Tellian thrust belt the heat flow increases rapidly towards the Mediterranean Sea. Its overall pattern is comparable to that measured in the other Tertiary belts (Takherist and Lesquer, 1989). According to these authors the present day heat flow varies from $80 \mathrm{~mW} / \mathrm{m}^{2}$ to more than $100 \mathrm{~mW} / \mathrm{m}^{2}$ near the offshore. At the present day 330 the geothermal gradient varies from $30-35^{\circ} \mathrm{C} / \mathrm{km}$ (Normal Geothermic Gradient) to 331 more than $50^{\circ} \mathrm{C} / \mathrm{km}$ (Fig. 12), two hyperthermic zones being localized in the central 332 part of the Chelif Basin, where it may be due to the local occurrence of Neogene 333 diapirs remobilizing the Triassic salt of the Tellian allocthon, (Fig. 2) and the coastal 334 zone near the Gulf of Mostaganem (i.e. in the vicinity of the neoformed Neogene

336 In the eastern part of the basin, the deduced heat flow varies from $50 \mathrm{~mW} / \mathrm{m}^{2}$ to 85 $337 \mathrm{~mW} / \mathrm{m}^{2}$ (Fig. 13a). For obvious geodynamic reasons, the heat flow model used in the present study has been considered variable through the geological time. From the 339 Upper Cretaceous to the Lower Miocene (main episodes of tectonic contraction), the 340 mean flow value is estimated to $50-55 \mathrm{~mW} / \mathrm{m}^{2}$. However, related to geodynamic and 341 volcanic activity of the basin, we assume a larger heat flow value since the onset of 342 slab detachment and Tortonian-Messinian episode of accelerated subsidence in the 343 basin (Fenet, 1975; Bellon and Brousse, 1977; Ait Hamou, 1987; Maury et al., 2000). 344 Ultimately, the present day heat flow has been deduced from the geothermal gradient 345 and thermal conductivities of the sediments. The BHT corrected temperatures 346 calibrated the present day heat flow at $85 \mathrm{~mW} / \mathrm{m}^{2}$ (Fig. 13a), as estimated by 


\subsubsection{Reconstruction of the burial history}

At eastern part of the study area, the Neogene series of the Chelif Basin were deposited on top of the Oligocene and Cretaceous Tellian allochthon (Figs. 1 and 2).

The Late Oligocene and Burdigalian being still characterized by deep water turbidites along the Tellian allochthonous units underlying the Neogene depocenters of the Chelif, only minor erosion occurred in this formerly basinal domain until the onset of uplift and tectonic accretion.

During the development of the Lower Miocene syn-compressional piggyback basin (Langhian-Serravallian) and subsequent transtensional opening of the thrust-top pullapart basin (Tortonian-Messinian), the sedimentation rate was very high $250 \mathrm{~m} / \mathrm{Ma}$ (Fig. 13b). Because of renewed transpressional foreland inversion in post-Miocene times, the sedimentation rate was lower than $100 \mathrm{~m} / \mathrm{Ma}$ (Fig. 13b) during both the Pliocene and Quaternary in the relict depocenters, most of the basin being instead impacted by inversion-related uplift and erosion.

In the western area (W10 well), the sedimentation rate recorded during the Upper

Cretaceous- Eocene period) is $30 \mathrm{~m} / \mathrm{Ma}$ (Fig. 14 a). However, during Upper MiocenePliocene period, this parameter reaches $80 \mathrm{~m} / \mathrm{Ma}$; this is related to the transtensional extension of the basin (Fig. 14 a).

\subsubsection{Hydrocarbon generation and expulsion histories}

1D thermal modelling has been undertaken with the Genex software on the W5 Well in the El-Biod area and W10 to the West (Fig. 1). The thermal calibration of the thermal model is established thanks to the measured temperatures in the well and the maturity mesurements (Ro converted values) (Fig. 13b). In the former area, the oil generation from the Middle Miocene formations (supposed source rocks) occurred 
374 from 12 to $10 \mathrm{Ma}$ and gas during 10-present day with a burial of $4000-5200 \mathrm{~m}$,

whereas, the Messenia is still immature (Fig. 13c). Besides, the Langhian supposed source expelled oil between 8 and $5 \mathrm{Ma}$ after that period only gas expulsion occurred in this deeper part of the basin (Fig. $13 \mathrm{~d}$ ).

In the western area, there are two picks of oil expulsion, the first pick happens between 12 and $8 \mathrm{Ma}$ while the second one between happens at 4- $2 \mathrm{Ma}$ (Pliocene) (Fig. 14b).

Besides, the formation of structural traps relate to the Pliocene and Quaternary inversion, thus post-dating the Messinian episode of maximum burial. Considering type-Il kerogen in this model, the Messinian which is the source rock of the Ain Zeft oil field was not buried enough there (at 1,000 m depth) to generate hydrocarbons. Alternatively, in the case of type-IIS kerogen as is shown by the $n$ alcanes and biomarkers distribution in the rock extracts, it could generate commercial amounts of oil at lower temperatures $\left(<50^{\circ} \mathrm{C}\right)$. A kinetic model of this organic matter would be required in order to confirm such scenario.

The Upper Cretaceous series are considered as the main source rock for the Upper Miocene reservoir in Tliouanet. They are probably also the source of the gas and oil shows documented elsewhere in the Chelif Basin (Fig. 1). The Middle Miocene series display some HC potential in the El-Biod area where the Miocene reservoirs might have been sourced from. The Ain Zeft heavy oil is originated from the Upper Miocene source rock which has also a good generation potential in this area (Figs. 1, 3 and Tab. 1). There are three types of traps, anticlines, roll-over structures and those associated to diapirs. Their age extend from Middle Miocene to Pliocene and even to present day. The early charge is most likely oil whereas the most recent traps could accumulate mainly gas. 


\section{Discussion}

\subsection{Petroleum systems analysis}

\subsubsection{Upper Cretaceous / basal Tortonian sandstone}

In the Tellian allochthon, the Upper Cretaceous (Cenomanian to Campanian) source rocks extend only away from the Neogene depocenters, i.e. mainly south of the Tliouanet- Relizane fields in the south (Fig. 1a), and north of the Ain Zeft field in the north, making it difficult to contribute in any way to the petroleum potential of the basin. Axtually, due to the Tortonian-Messinian extension, Neogene series rest almost directly above the sole thrust of the Tellian allochthon in the central part of the basin (Fig. 2), where coeval Upper Cretaceous source rocks are instead likely to be found at appropriate depth for $\mathrm{HC}$ generation in the underthrust foreland and parautochthonous subthrust prospects.

412 Although the presence of a thick Miocene sandstones package $(200 \mathrm{~m})$ in Djebel 413 Djira area, to the west, there is no petroleum perspective because of the absence of 414 the source rocks (Fig. 15).

415 The zone B (Fig. 15) is the most prospective thanks to the presence of reservoirs at 416 the base of the Upper Miocene and the presence of both Upper Cretaceous and 417 Upper Miocene source rocks. However, as far as the exploration results are 418 concerned, and with the exception of the Ain Zeft accumulation, there have been only 419 dry holes and hydrocarbon shows. The deficient parameter of the petroleum system 420 in the whole Neogene sedimentary infill of the Chelif Basin is the timing of the trap 421 formation as compared to hydrocarbon migration. This is the case for instance for 422 Pliocene and Quaternary structures. The presence of the small accumulation in 423 Sadra area (Sedra well, eastern part) resulted either from a migration during the 
424 structuration or from a remigration from a deeper accumulation. Such accumulation is 425 not commercial.

.

In Ain Zeft, Akboub and Hellil areas, the presence of the light oils, more mature than the rock extracts of the nearby source intervals, clearly require the occurrence of a deeper kitchen and both long range lateral and vertical migration, either from deepest parts of the pull-apart basin, or from the lower plate, using the main border faults of the basin to migrate from the underthrust units towards the Neogene pull-apart.

The zone $\mathrm{C}$ (Fig. 15) is the deepest part of the basin, it is characterized by a high sedimentation rate, varying from 100 to $1000 \mathrm{~m} / \mathrm{ma}$ (Fig. 13b) during the Miocene. This might have caused dilution of the organic matter. Such sedimentological conditions and probably the absence of upwelling streams could not favor a development of anoxic conditions during Miocene time.

\subsubsection{Messinian (source rock)/ Upper Miocene/Pliocene reservoirs}

The Upper Miocene (Messinian) source rock extends along central part of the basin, Dahra Mountain and Ai Zeft area (Fig. 15). To be effective, this petroleum system would require the presence of Upper Miocene reservoirs, i.e. the basal Tortonian sandstone and Pliocene algal limestones (Lithotamnium limestone) and relatively old (pre-Pliocene) structures. The generation of the hydrocarbon from Messinian source rock is also conditioned by the thickness of the Pliocene sediments (burial).

Besides, the hydrocarbon charge of the Upper Miocene reservoirs could relate from deep Neogene kitchens or again, from a vertical migration across the sole thrust of the Tellian allochthon, from Upper Cretaceous source rocks from the lower plate. Although a thick Pliocene series (500 à 1000 m) (Fig. 3) occurring at Fekrane and Belkheir areas (which could host both reservoirs and seals), there is a challenge for 
developing any commercial hydrocarbon accumulation in relationship with this play, because of the lack of source rocks therein. Elsewhere, the Pliocene series are thinner (because mainly of Quaternary erosion), ranging from 0 to $50 \mathrm{~m}$, which is clearly insufficient to expect any sealed reservoir there.

\section{Conclusions}

The Oligocene Numidian series display locally high organic contents in Sicily and Tunisia, where they are known to account for effective petroleum systems (El Heuchi et al., 2004; Granath and Casero, 2004). Despite the fact that no hydrocarbon field has yet been discovered in Oligocene Numidian sandstones in Northern Algeria, the Oligocene series of the Tellian allochthon in the vicinity of the Chelif Basin shows the same overall characteristics, and could still constitute a target for the exploration. In the more than $4 \mathrm{~km}$-thick pre-Messinian Miocene series, there are intervals with a mean organic richness (TOC) comprised between 0.5 and $1 \%$, but their generative potential still remains low because of the bad preservation of the organic matter, which is marine with slight continental contribution. The optical observation and the low residual potential $(\mathrm{HI})$ show that there is an effect of oxidation. In contrast, the Tripoli member of the Messinian series displays a very high organic content, with TOC values up to $10 \%$ or more, but low maturities (Tmax $<430^{\circ} \mathrm{C}$ ). However, its kerogene is of the type-IIS, which could generate hydrocarbon even at low temperatures $\left(<50^{\circ} \mathrm{C}\right)$. Alternatively, the Upper Miocene is more buried in the main depocenters of the Chelif Basin than in the modelled wells, implying that it could be already in the oil window in the deepest, not yet inverted parts of the basin. The 1D basin modeling shows that the timing of oil generation from the Middle Miocene source rock occurred during the Upper Miocene and Pliocene period. Considering the 
richest levels of the Middle Miocene source rocks, the oil expulsion began at $8 \mathrm{Ma}$. From $5 \mathrm{Ma}$ to the Present day, mainly gas expulsion occurred. In any case, the GC/GCMS analysis confirms the correlation between Aïn Zeft oils, which contain oleanane, and Upper Miocene extracts. However, the main exploration risk for Neogene hydrocarbon systems relates to the scarcity of clastic reservoirs in the sedimentary infill of the pull-apart basin, most anticlinal structures being controlled by salt domes, with dominantly fine grain growth strata. Stratigraphic traps and sandy paleo-chanels would rather occur along the flanks of the structures or in intervening lows, but they can hardly be identified here due to the lack of 3D seismic. PlioQuaternary anticlines related to the recent inversion of the basin are likely to postdate the episodes of maximum burial in the Miocene depocenters, even if they could host remigrated oils from older structures, or oil escaping vertically from the substhrust units along vertical conduits such as the main border fault of the basin. Similar modes of petroleum charge is known to occur in the Vienna Basin in Austria for instance, were the oil generated in Jurassic source rocks from the lower plate have migrated upward across the Alpine nappes before to be trapped in Neogene clastics of the trust-top pull-apart basin (Sauer et al., 1992; Seifert, 1996).

491 The Cenomanian source rocks of the Tellian allochthon constitute frequently 492 discontinuous blocks reworked in tectonic melanges along the sole thrust of the 493 Tellian allochthon, or shallow erosional remnants between the main Neogene 494 depocenters and the frontal Tellian thrust. Due to the Tortonian-Messinian extension, 495 it is unlikely that thick Cenomanian series are still preserved in the allochthon benath 496 the Chelif Basin itself. Alternatively, the occurrence of oils with a geochemical inprint 497 of Upper Cretaceous source rocks in the Tliouanet field near the main border fault of 498 the Chelif Basin rather suggests a dismigration from the underthrusts foreland or 
499 parautochthonous structures which formed during the Plio-Quatenary episode of

transpression, making the subthrust plays a potential target. The main exploration risk here would relate to the possible erosion of Cretaceous platform carbonate reservoirs and Albian sands of subthrust prospects prior to the development of the Neogene foreland flexure and deposition of deep water seals, due to Late Cretaceous to Eocene episodes of foreland inversion (Roure et al., 2012).

\section{Acknowledgements}

507 This work was undertaken as part of a Master II research work realized at USTHB 508 University (Algiers). The authors wish to thank Sonatrach and Alnaft for giving us 509 access to well data. We acknowledge M. Kaced and N. Yahi for reviewing an early 510 draft of the manuscript. We greatly benefited from discussions with $\mathrm{A}$. Lassal and $\mathrm{H}$. 511 Benali.

\section{References}

514 Aiffa, T., Feinberg, H., Derder, M. M., Merabet, N. E., 1992. Rotations 515 paléomagnétiques récentes dans le bassin du Chélif (Algérie). Comptes Rendus de 516 l'Académie des Sciences, Paris, 314, Série II, 915-922.

518 Aït Hamou, F., 1987. Etude pétrographique et géochimique du volcanisme d'âge 519 Miocène de la région de Hadjout (Ouest Algérois). Thèse de magister, Université des 520 Sciences et de la Technologie Houari Boumediene, Bab Ez Zouar, Algiers, Algeria, $521 \quad$ p. 222. 
523 Béhar, F., Huc, A., Da Silva, M., IFP-Sonatrach Tell-Offshore Team, 2006.

Geoschemistry of source rocks and oils. In Roure F., Addoum, B. et al., Architecture and petroleum appraisal of Northern Algeria. IFP-Sonatrach report, $N^{\circ} 59520$, TellOffshore JIP, Volume 1, 83-90, unpublished.

Bellon, H., Brousse, R., 1977. Le magmatisme périméditerranéen occidental: essai de synthèse. Bulletin de la Société Géologique de France 7, 469-480.

Benaouali-Mebarek, N., Frizon de Lamotte, D., Roca, E., Bracène, R., Faure, J. L., Sassi, W., Roure, F., 2006. Post-Cretaceous kinematics of the Atlas and Tell systems in central Algeria: Early foreland folding and subduction related deformation. Comptes Rendus Géosciences 338, 115-125.

536 Boudiaf, A., Ritz, J. F., Philip, H., 1998. Drainage diversions as evidence of propagating active faults: example of the El Asnam and Thenia Faults, Algeria. Terra Nova $10,236-244$.

540 Bracène, R., Frizon de Lamotte, D., 2002. The origin of intraplate deformation in the Atlas system of western and central Algeria: from Jurassic rifting to CenozoicQuaternary inversion. Tectonophysics 357, 207-226.

Carminati, E., Wortel, M. J. R., Meijer, P. Th., Sabadini, R., 1998. The two-stage opening of the western-central Mediterranean basins: a forward modelling test to a new evolutionary model. Earth and Planetary Sciences Letters 160, 667-679. 
Casero, P., Roure, F., Vially, R., 1991. Tectonic framework and petroleum potential

of the southern Apennines. In: Spencer, A.M. (Eds.), Generation, Accumulation and

Production of Europe's Hydrocarbons, Oxford University Press, U. K., 1991, pp. 381551387.

Derder,M. E. M., Henry, B., Maouche, S., Bayou, B., Amenna, M., Besse, J., 554 Bessedik, M., Belhai, D., Ayache, M., 2013. Transpressive tectonics along a major 555 E-W crustal structure on the Algerian continental margin: Blocks rotations revealed 556 by a paleomagnetic analysis. Tectonophysics 193, 183-192.

Domzig, A., Yelles, K., Le Roy, C., Deverchère, J., Bouillin, J. P., Bracène, R., 
573 Espitalié, J., Deroo, G. and Marquis, F., 1985. La pyrolyse Rock-Eval et ses 574 applications. Revue de l'Institut Français du Pétrole 40, 563-578.

576 Fenet, B., 1975. Recherches sur l'Alpinisation de la bordure septentrionale du 9577 Bouclier Africain, à partir de l'étude d'un élément de l'Orogenèse nord-maghrébin: 
Hsü, K. J., 1971. Origin of the Alps and Western Mediterranean. Nature, 233, 44-48.

Karakitsios, V., 2013. Western Greece and Ionian sea petroleum systems. American Association of Petroleum Geologists Bulletin 97 (9), 1567-1595.

Lingrey, S., 2007. Cenozoic deformation of Trinidad: Foldbelt restoration in a region of significant strike-slip. In: Lacombe O., Roure, F., Lavé, J. \& Vergés, J. (Eds.), Thrust belts and foreland basins, Frontiers in Geosciences, Springer, 2007, pp. 163178.

611 Masrouhi, A., Koy,i H., 2012. Submarine "salt glacier" kinematics of Northern 612 Tunisia, a case of Triassic salt mobility in North African Cretaceous passive margin. 613 In: Alsop, G. I, Archer, S. G, Hartley, A, Grant, N.. T, Hodgkinson, R. (Eds.), Salt 614 Tectonics, Sediments and Prospectivity. Geological Society, London, Special 615 Publications, 363, 2012, pp. 579-593.

Maury, R.G., Fourcade, S., Coulon, C., El Azzouzi, M., Bellon, H., Coutelle, A., Ouabadi, A., Semroud, B., Megartsi, M., Cotton, J., Bellanteur, O., Lounil-Hacini, A., 
622 Piqué, A., Capdevila, R., Hernandez, J., Rehault, J.P., 2000. Post-collisional

Neogene magmatism of the Mediterranean Maghreb Margin: a consequence of slab breakoff. Comptes Rendus de l'Académie des Sciences, Paris, 331, 159-173.

Meghraoui, M., 1982. Etude néotectonique de la région nord-est d'El Asnam, relation avec le séisme du 10/10/1980. PhD Thesis, $3^{\circ}$ Cycle, Université de Paris VI, France, p.190.

630 Meghraoui M., Cisternas A., Philip H., 1986. Seismotectonics of the lower Chelif 631 Basin: structural background of the El -Asnam (Algeria) earthquake. Tectonics 5 (6), $632 \quad 809-836$

634 Meghraoui, M., Doumaz, F., 1996. Earthquake-induced flooding and paleoseismicity 635 of the El Asnam (Algeria) fault-related fold. Journal of Geophysical Research 101, $636 \quad 17617-17644$

638 Mekki, F., Bouslah, S., 2001. Caractérisation géochimique de l'huile d'Aïn Zeft. 639 Sonatrach- CRD Internal Report, 195/01.2039, unpublished.

641 Neurdin-Trecartes, J., 1992. Le remplissage sédimentaire du bassin néogène du 642 Chélif, modèle de référence de bassins intra-montagneux. PhD Thesis, Thèse d'Etat, Académie de Bordeaux, France, p. 605.

645 Neurdin-Trecartes, J., 1995. Paléogéographie du bassin de Chélif (Algérie) au 646 Miocène. Causes et Conséquences. Géologie Méditerranéenne, XXII, 2, 61-71. 
Perrodon, A., 1957. Etude géologique des bassins néogènes sublittoraux de

l'Algérie occidentale. PhD Thesis, Nancy Univ., Publication du Service de la Carte 650 Géologique de l'Algérie, Bulletin N²12,328pp.

Philipe H., Meghraoui, M., 1983. Structural analysis and interpretation of the surface deformation of the El Asnam earthquake of October 10, 1980, geodetic determination of vertical and horizontal movements. Bulletin Seismological Society of America 72, 2227-2224.

Roure, F., Addoum, B. et al., (2006). Architecture and petroleum appraisal of 670 Northern Algeria. IFP-Sonatrach report, 59520, Tell-Offshore JIP, Volume 1, 188pp, 671 unpublished.

Piqué, A., Aït Brahim, L., Aït Ouali, R., Amrhar,, M., Cherroud, M., Courmelen, C., Laville, E., Rekhiss, F., Tricart, P., 1998. Evolution structurale des domaines atlasiques du Maghreb au Méso-Cénozoïque; le rôle des structures héritées dans la déformation du domaine atlasique de l'Afrique du Nord. Bulletin de la Société Géologique de France 169 (6), 797-810.

Rebaï, S., 1993. Recent tectonics in northern Tunisia: coexistence of compressive and extensional structures. Annales Tectonicæ 7, 129-141.

Roure, F., 2008. Foreland and hinterland basins: what controls their evolution?, Swiss Journal of Geosciences 101, 1-24. 
673 Roure, F., Casero, P., Addoum, B., 2012. Alpine inversion of the North African 674 Margin, and delamination of its continental crust. Tectonics, 31, TC3006, 675 doi.1029/2011 TC002989.

677 Royden, L. H., 1985: The Vienna Basin: a thin-skinned pull-apart basin. In: Biddle 678 K.T., and Christie-Blick N. (Eds.), Strike-slip deformation, basin formation and 679 sedimentation. SEPM Society for Sedimentary Geology, Special Publication, 37, 6801985 , pp. 313-338.

Sassi, W., Mechti, M., Yessad, S., Roure, F., The Tell-Offshore Team, 2006. In: 683

Roure, F., Addoum, B. et al., Architecture and petroleum appraisal of Northern 684 Algeria. IFP-Sonatrach report, 59520, Tell- Offshore JIP, Volume 1, 121-134 685 unpublished.

687 Sauer, R., Seifert, P., Wessely, G. 1992. Guidebook to excursion in the Vienna 688 Basin and the adjacent Alpine-Carpathian thrust belt in Austria. Mitteilungen der 689 Österreichischen Geologischen Gesellschaft, 85pp.

691 Seifert, P. 1996: Sedimentary-tectonic development and Austrian hydrocarbon 692 potential of the Vienna Basin. In: Wessely, G. \& Liebl, W. (Eds.), Oil and gas in 693 Alpidic thrust belts and basins of Central and Eastern Europe. European Association 694 of Geological Enginering Special Publication, 5, 1996, pp. 331-342. 
696 Spakman, W., Wortel, R., 2004. A tomographic view on Western Mediterranean 697 geodynamics. In: Cavazza et al., (Eds.), The TRANSMED Atlas: The Mediterranean 698 Region From Crust to Mantle, Springer, New-York, 2004. Pp. 31-52.

700 Takherist, D., Lesquer, A., 1989. Mise en évidence d'importantes variations 701 régionales de flux de chaleur en Algérie, Canadian Journal of Earth Sciences 26, 702 615- 626.

occidental (Algérie), durant le Mio-Plio-Quaternaire. PhD, Thèse d'Etat, Université de 706 Pau et des pays de l'Adour, France, p. 594.

Vially ,R., Letouzey, J., Bénard F., Haddadi, N., Desforges, G., Askri, H., Boudjema, 709 A., 1994. Basin inversion along the North African margin: The Saharan Atlas (Algeria). 710 In: Roure F.(Eds.), PeriTethyan Platforms, Editions Technip, Paris, 1994, pp. 79-117.

Vila, J. M., 1994. Mise au point des données nouvelles sur les terrains triasiques des confins algéro-tunisiens: Trias allochtone, "glacier de sel" sous-marins et vrais diapirs. 
722 Yelles-Chaouche, A., Boudiaf, A., Djellit, H., Bracène, R., 2006. La tectonique active

Ziegler, P., Roure, F., 1996. Architecture and petroleum systems of the Alpine orogen and associated basins. In: Ziegler P. and Horvath F. (Eds.), PeriTethys, Mémoire. 2, Museum de l' Histoire Naturelle, Paris, 1996, pp. 15-46. 
Figures captions

2 Figure 1. (a) Geological setting of Chelif Basin and well location map and petroleum 3 results (b).

4

5 Figure 2. Regional structural cross-section of the Chelif Basin, outlining the Neogene 6 flexural basin, the Langhian and Mesozoic series of the underthrust foreland, the 7 Tellian allochthon, and the Tortonian-Messinian series of the thrust-top pull-apart 8 basin and the main hydrocarbon kitchens and petroleum plays.

9

10 Figure 3. Typical Neogene stratigraphic and lithological section of the Chelif Basin 11 and its substratum.

12

13 Figure 4. Geochemical log (Rock-Eval data) of Miocene section (El Biod, Well W5).

14

Figure 5. Geochemical log (Rock-Eval data) of Miocene section (Ain Zeft field, Well 16 W3).

18 Figure 6. Maturity indication: S2/TOC diagram of different source rocks.

Figure 7. HI Vs. Ol diagram of Miocene organic matter, Akboub, Hellil areas and 21 outcrops samples.

Figure 8. HI Vs. Tmax diagram of Miocene organic matter (Well W6 and outcrops 24 samples ). 
26 Figure 9. Ternary diagram HCS-HCA-NSO for oils and rock extracts.

28 Figure 10. $\mathrm{Pr} / \mathrm{hC} 17 \mathrm{Vs}$. $\mathrm{Ph} / \mathrm{nC} 18$ graph of oil indices and rock extracts of Oligocene 29 and Miocene stratigraphic levels.

31 Figure 11. Gas chromatogram traces of $\mathrm{nC} 14+$ saturates in the source rock extracts 32 and oils.

33 (a) Oil fraction from Upper Miocene reservoir (Well W3; Ain Zeft field).

(b) Messinian hydrocarbon extract (Mesinian marls from outcrops of Ain Zeft area).

(c) Oil fraction from Upper Miocene reservoir (Tliouanet field).

(d) Upper Cretaceous hydrocarbon extract (Western Tellian domain).

38 Figure 12. Geothermical gradient map $\left({ }^{\circ} \mathrm{C} / \mathrm{Km}\right)$ of Chelif basin.

40 Figure 13. (a, b, c and d) Results of 1D Genex modelling of the burial history and 41 hydrocarbon generation in El-Biod area (Well W5).

43 Figure 14. ( $a$ and $b$ ) Results of 1D Genex modelling of the burial history and 44 hydrocarbon generation in Akboub area (Well W10).

46 Figure 15. Extension of upper Cretaceous source rock and zonation in terms of 47 prospectivity of Upper Cretaceous (SR)/basal Tortonian (reservoir) petroleum 48 system. 
50 Table 1. Geochemical parameters based on TOC cut-off $>0.5 \%$ from Rock Eval 51 Pyrolysis and optical measurements (TOC: Total Organic Carbon; HI: Hydrogen 52 Index; TAl: Thermal Alteration Index).

53 


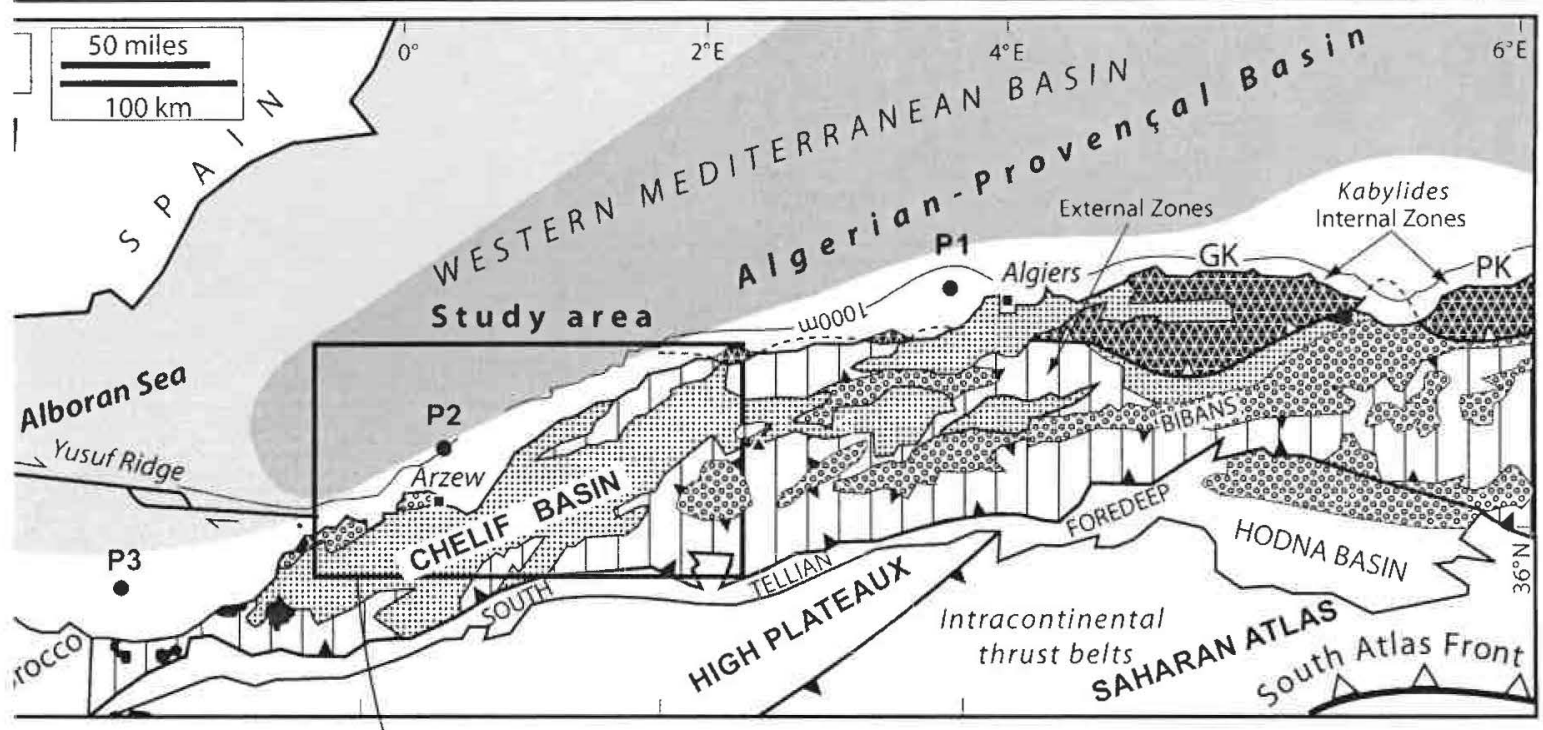

Neogene basins

(Post-nappe basins

and foreland flexural basins

Tell (allochton)

(mainly Numidian flysch)

Tell (parautochton)

Mesozoic series

Kabyle Crystallin allochton

GK:Grande Kabylie

PK:Petite Kabylie

Volcanic rocks

Oceanic Crust L_ Continental

Temoulga and Doui:epi-metamorphic ma:

External zones Alpine

internal zones (ALKAPECA) chain

Tellian thrust front
Thrusts
(D) and P2: DSDP
(Deep Sea Drilling Project) wells

P3 : exploration well

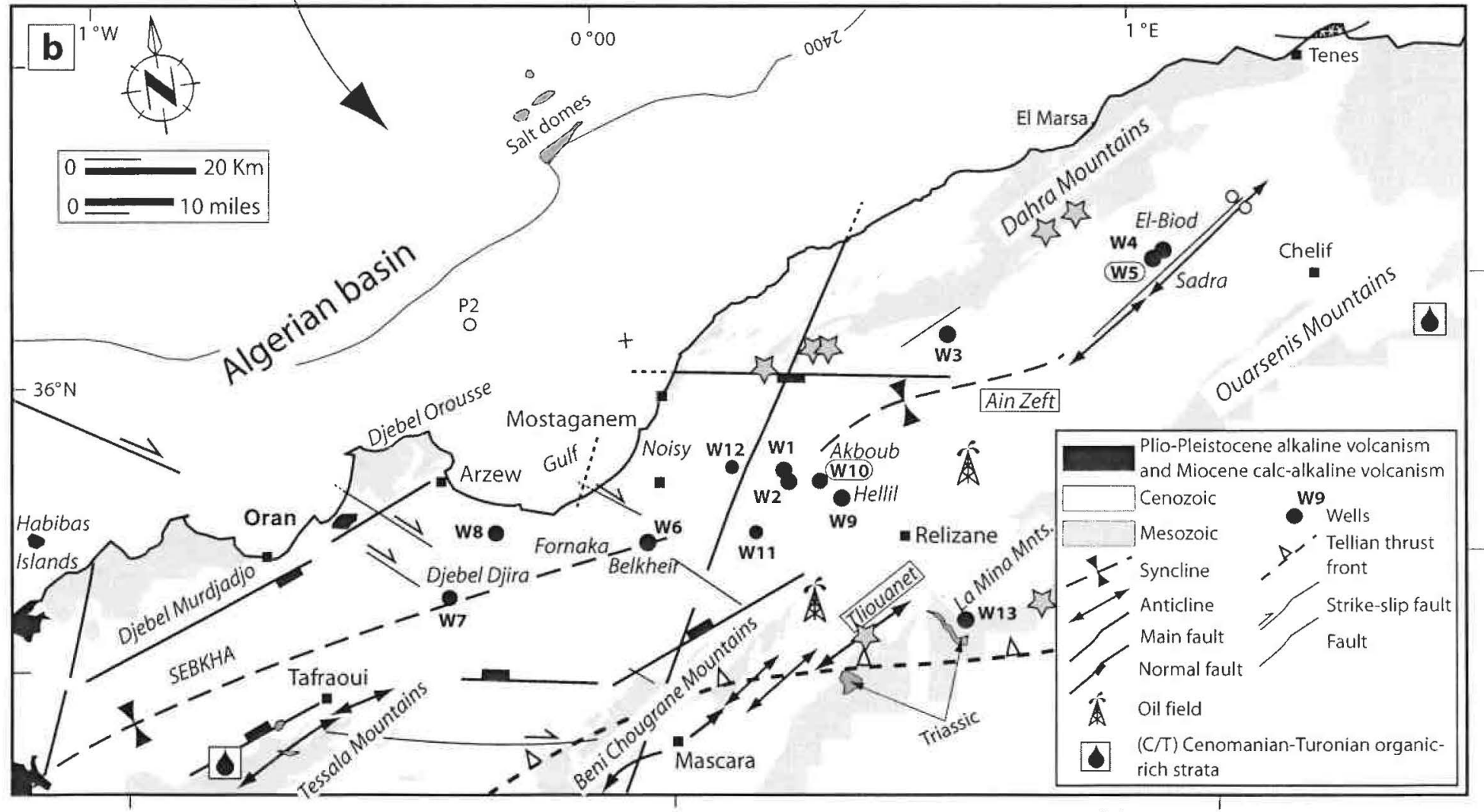

$\checkmark$ Location of the outcrops samples 


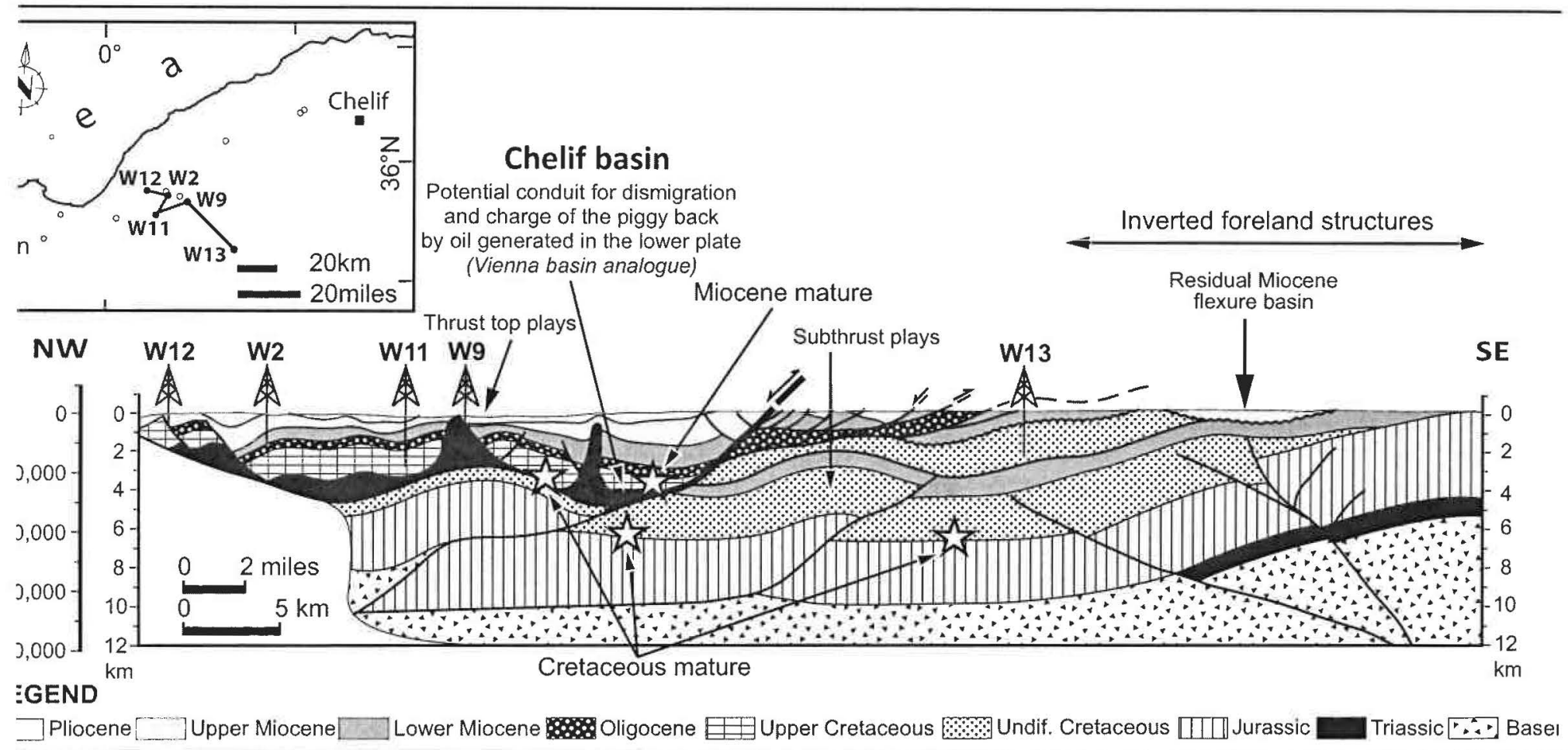


ure_3 CHELIF BASIN

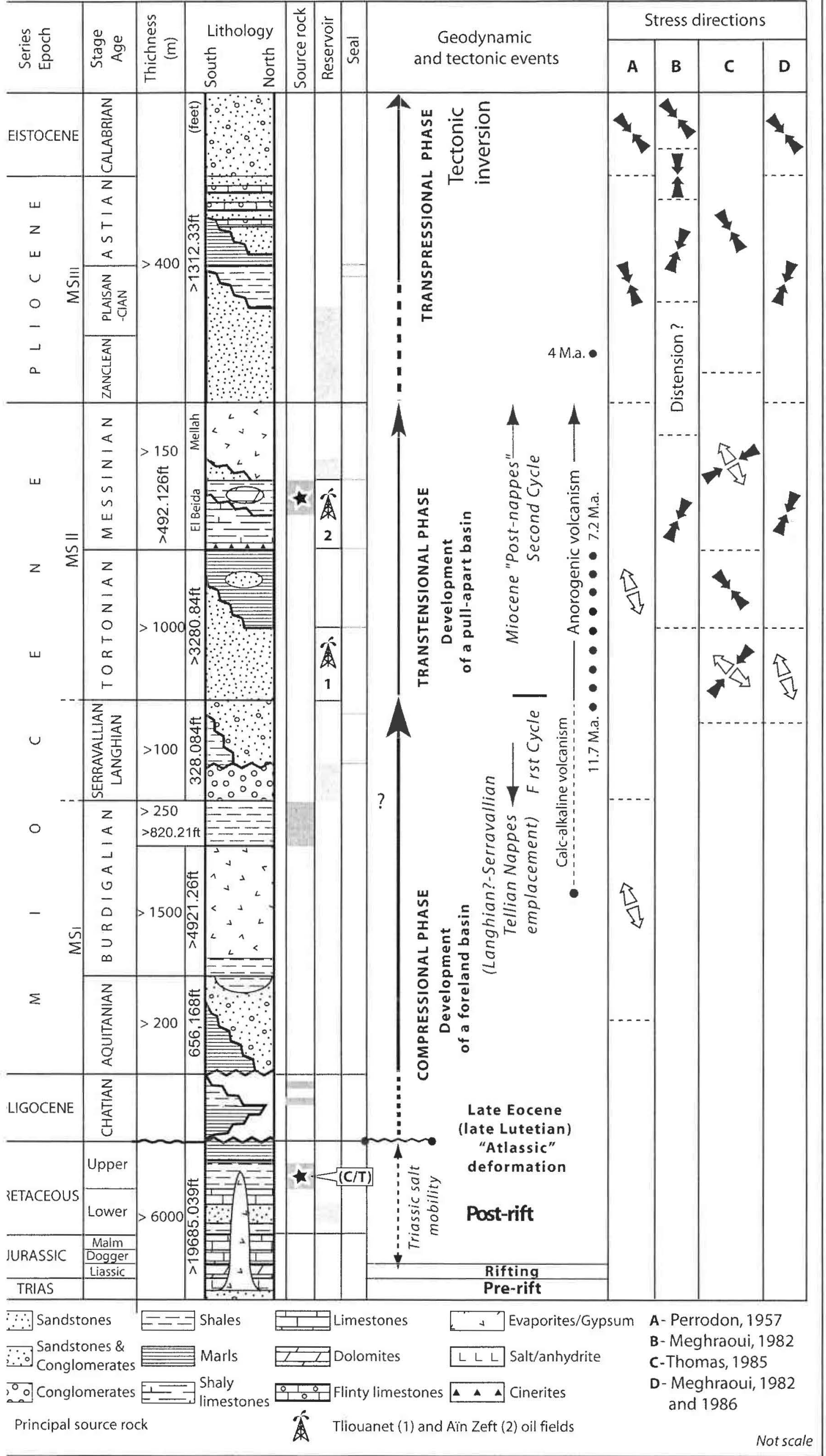




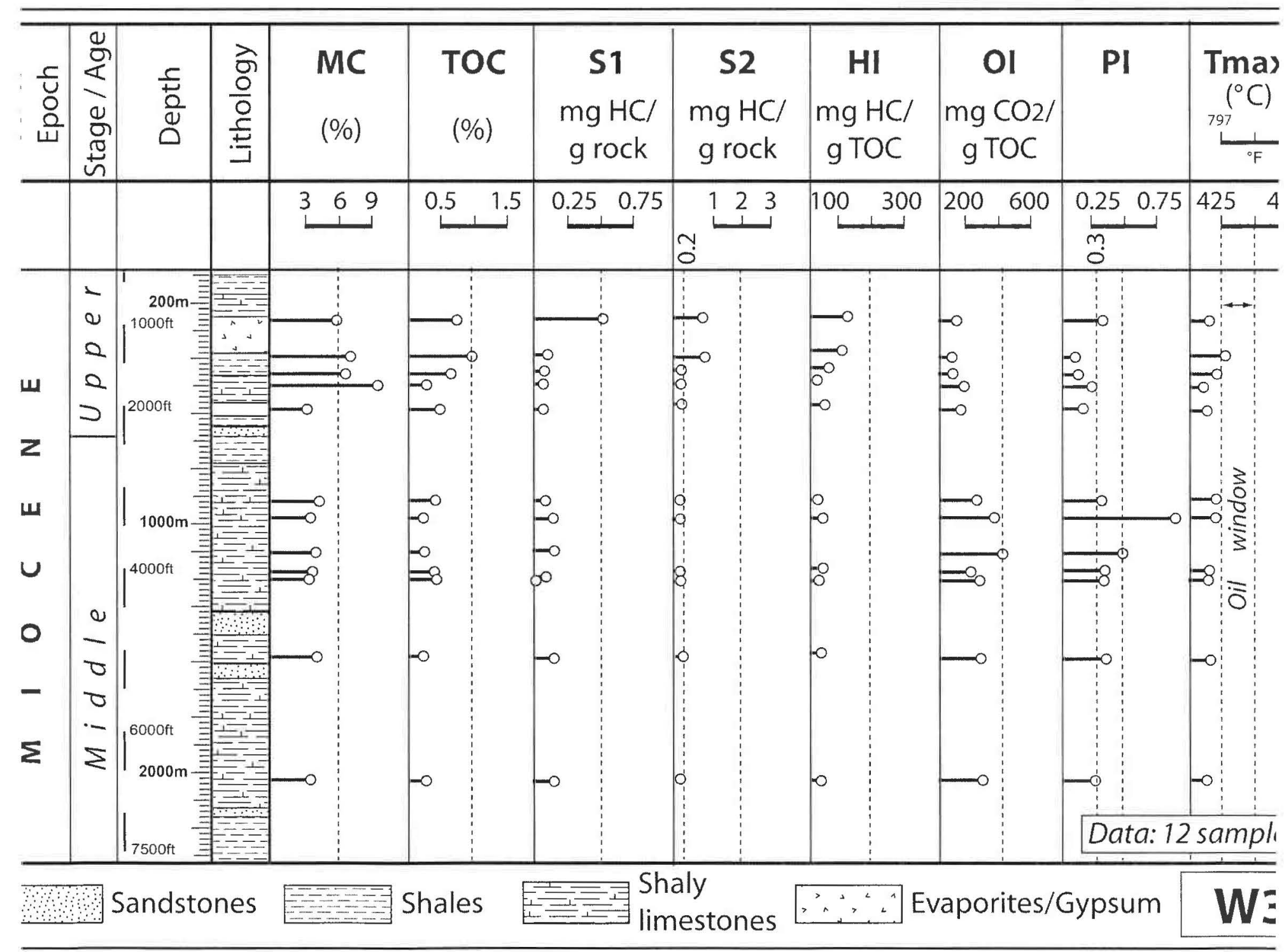


ure_6

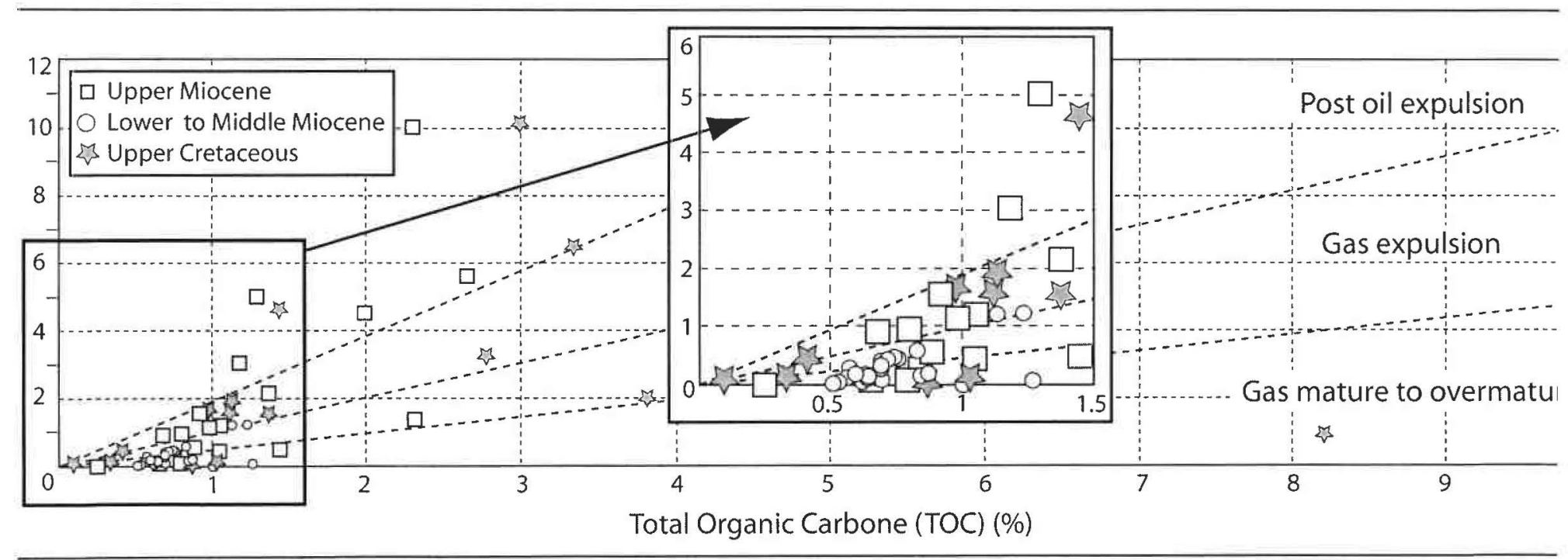




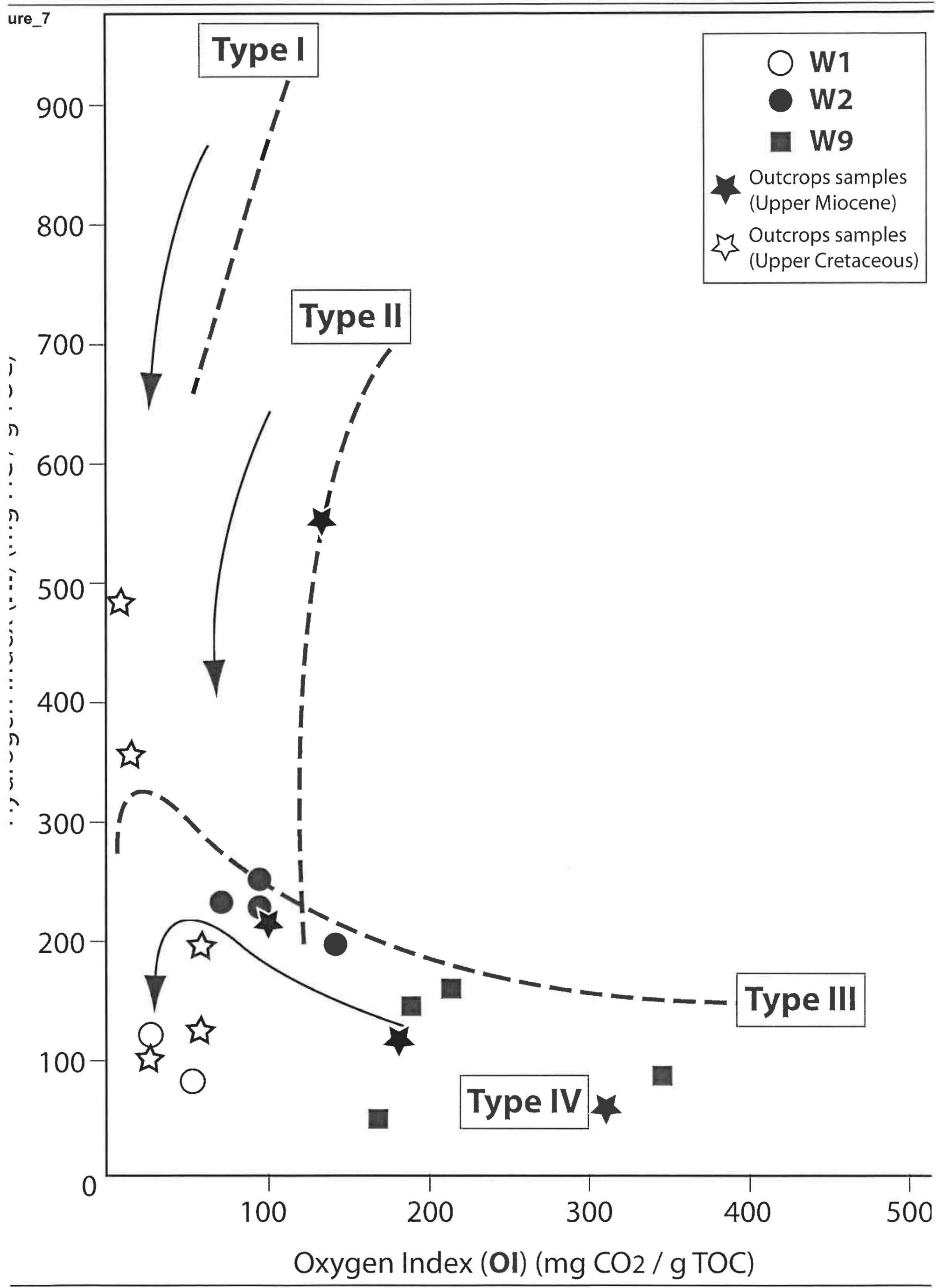


Aromatic H.C.

HCA

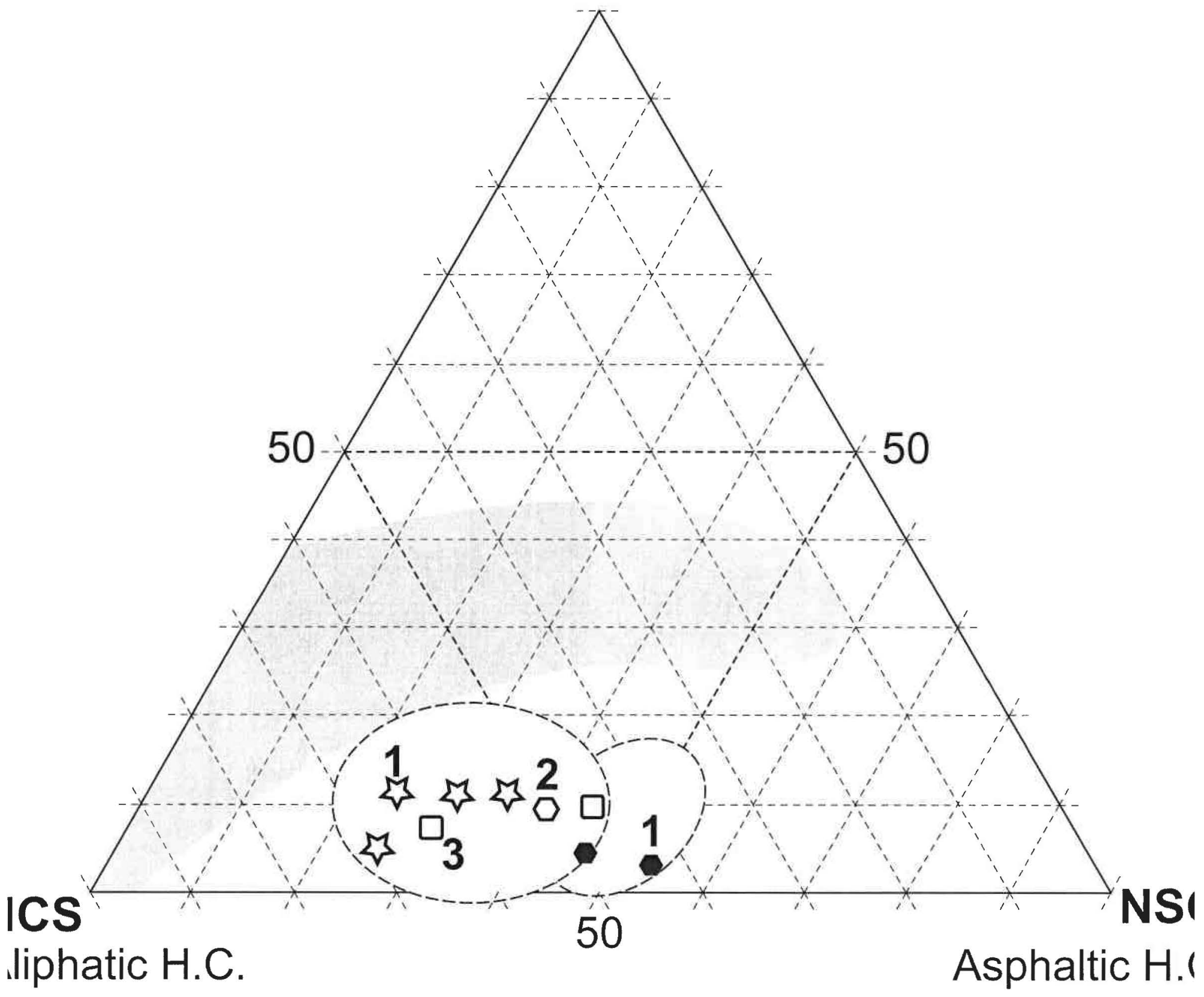

Rock extracts Hellil area (W9)

$\checkmark$ 1- Oligocene (W9)

Oils [Aïn Zeft (AZ-4), Akboub (W1) and El Biod (W4)]
1- Upper Miocene (W3)
$\checkmark$ 2- Middle Miocene (W4)
$\square$ 3- Oligocene (W1) 


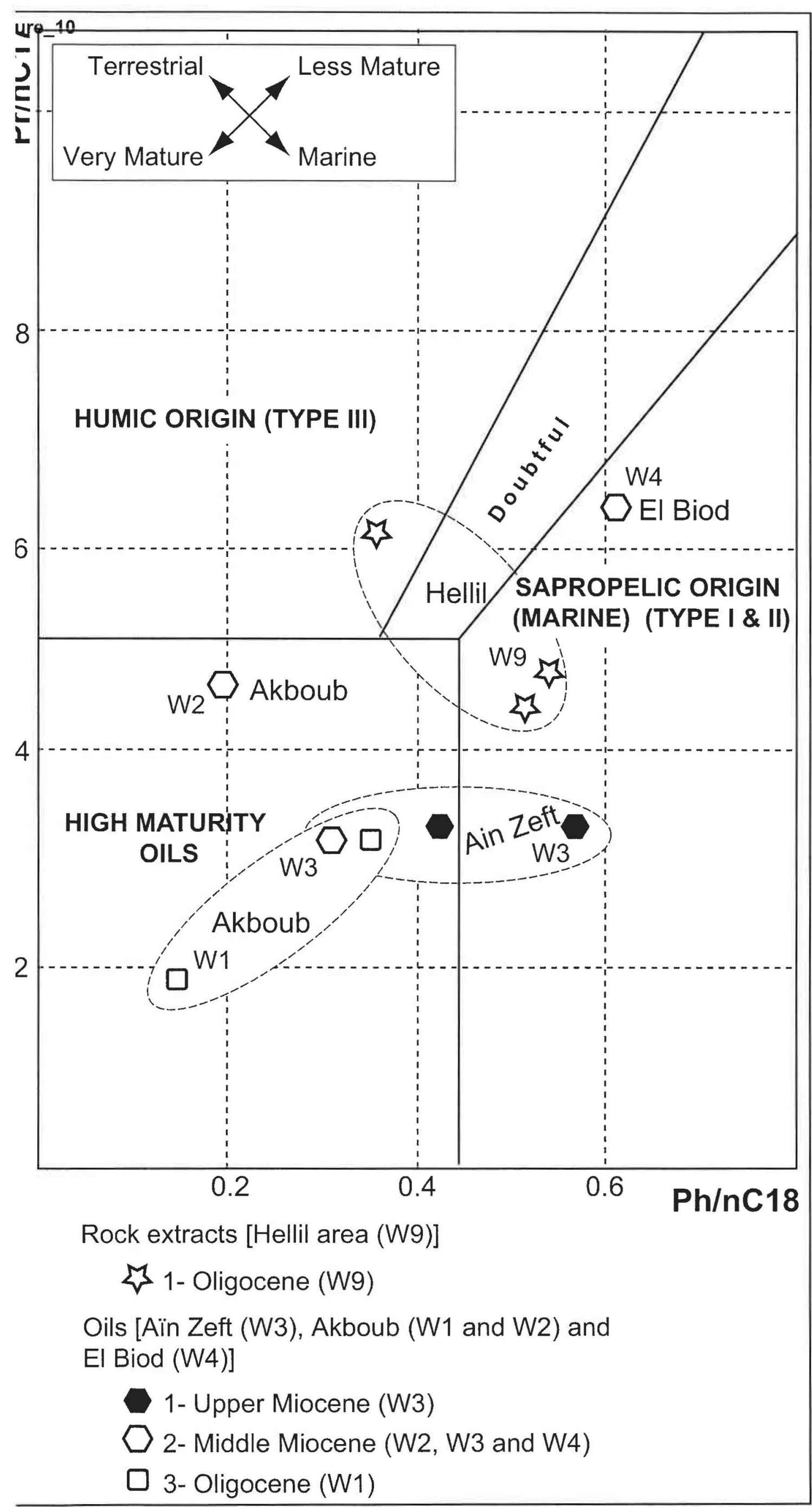


ure_11

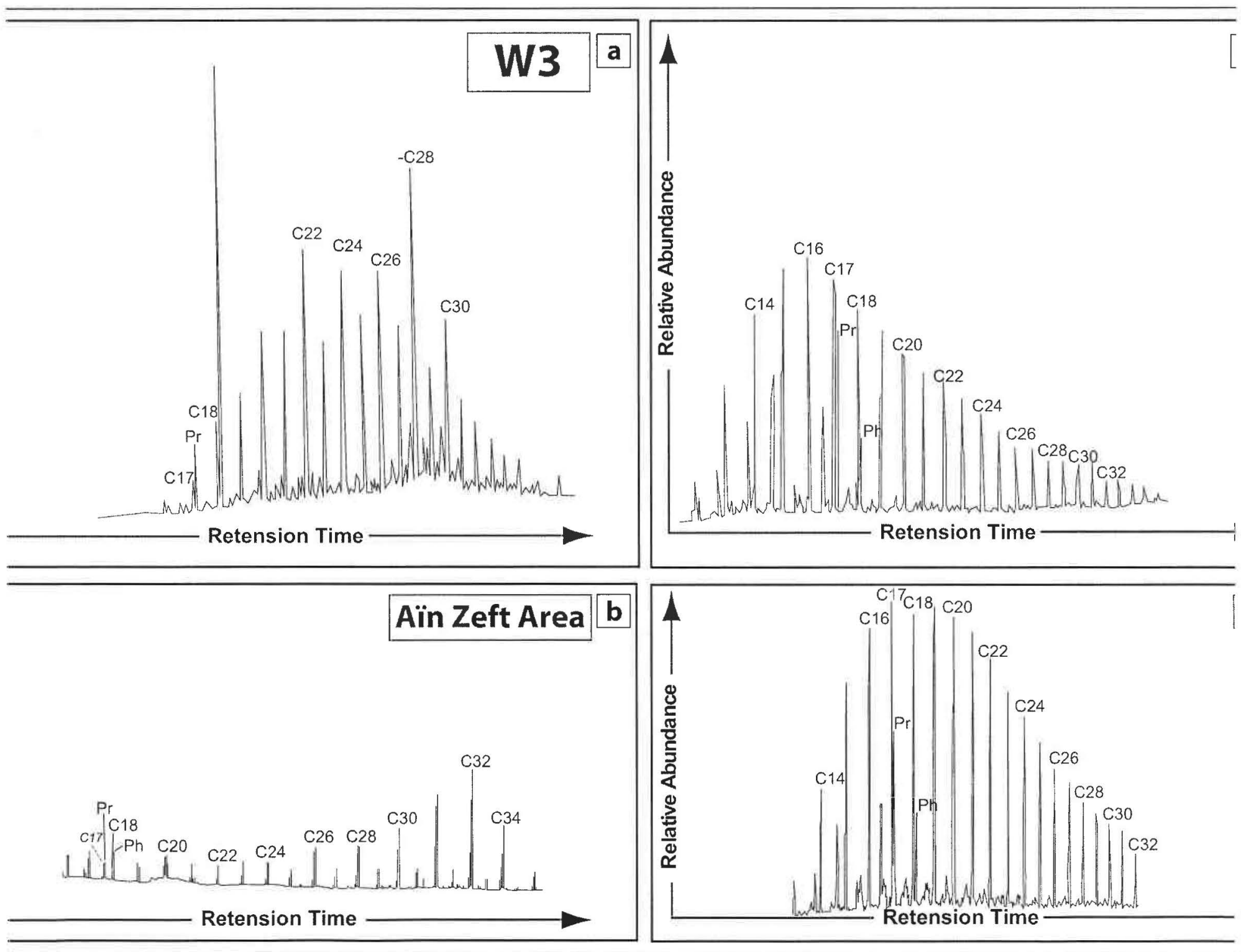




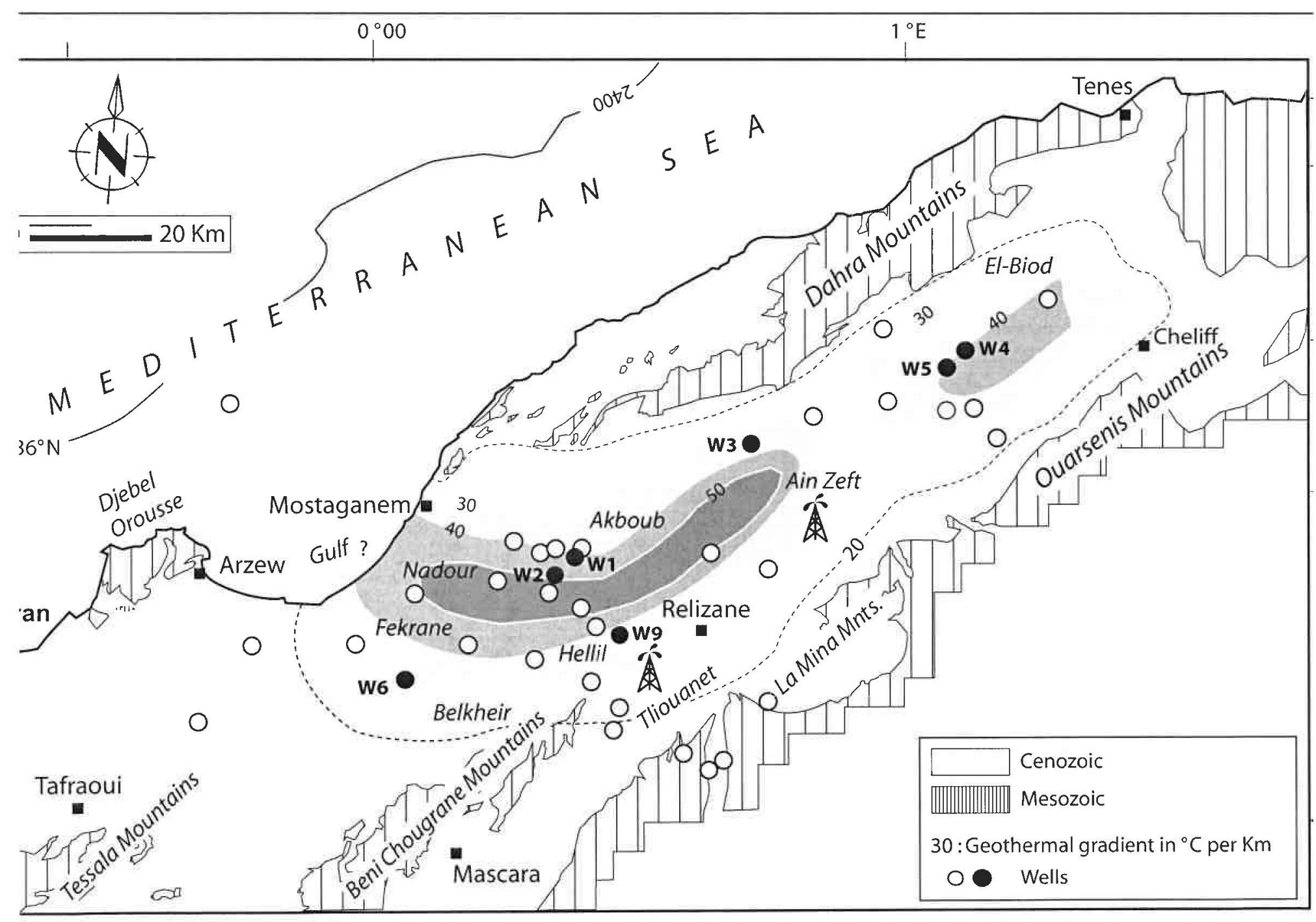




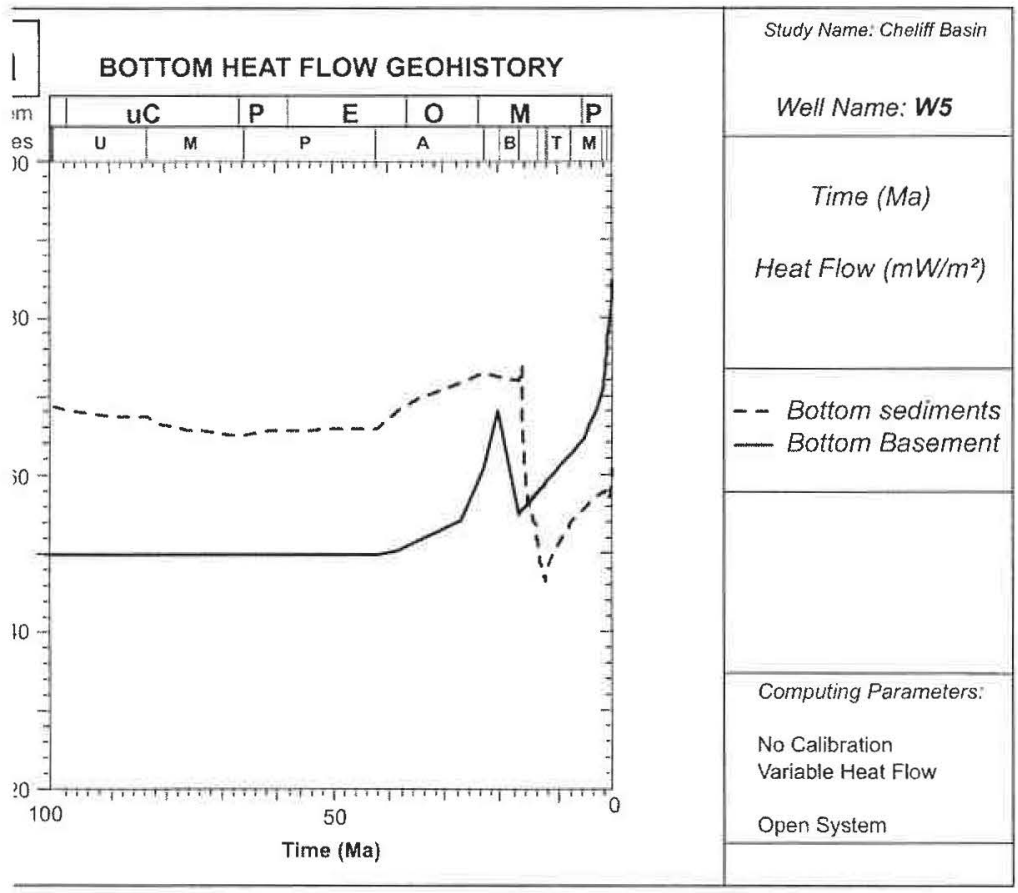

EXPELLED HC PER TIME INTERVAL

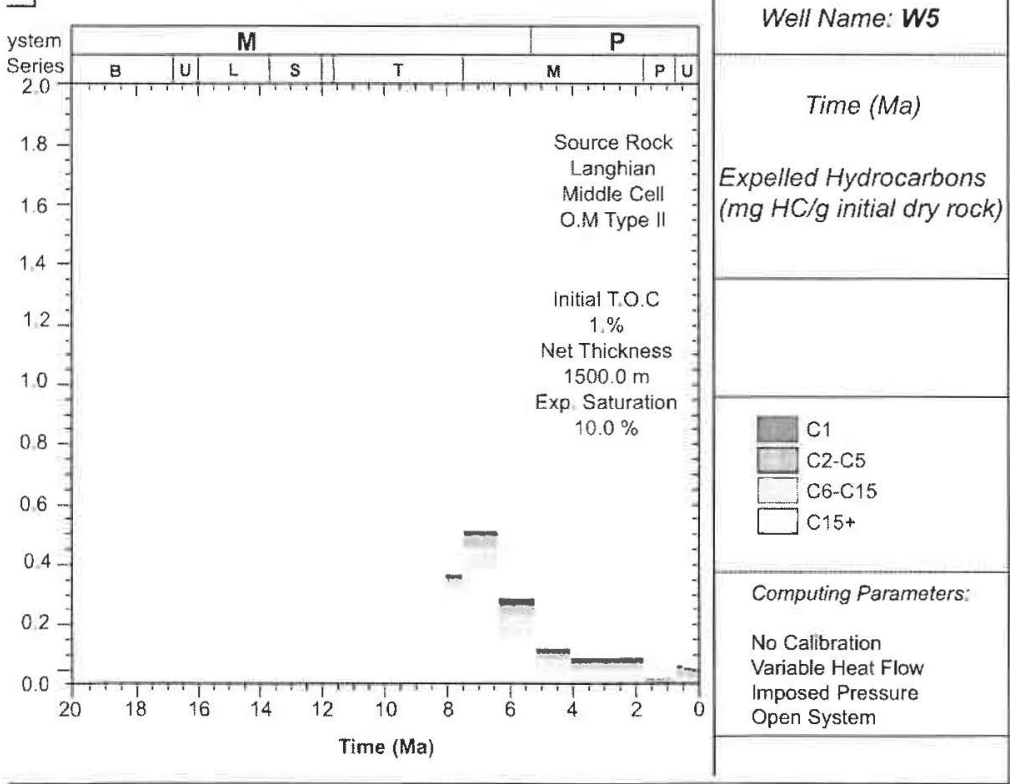

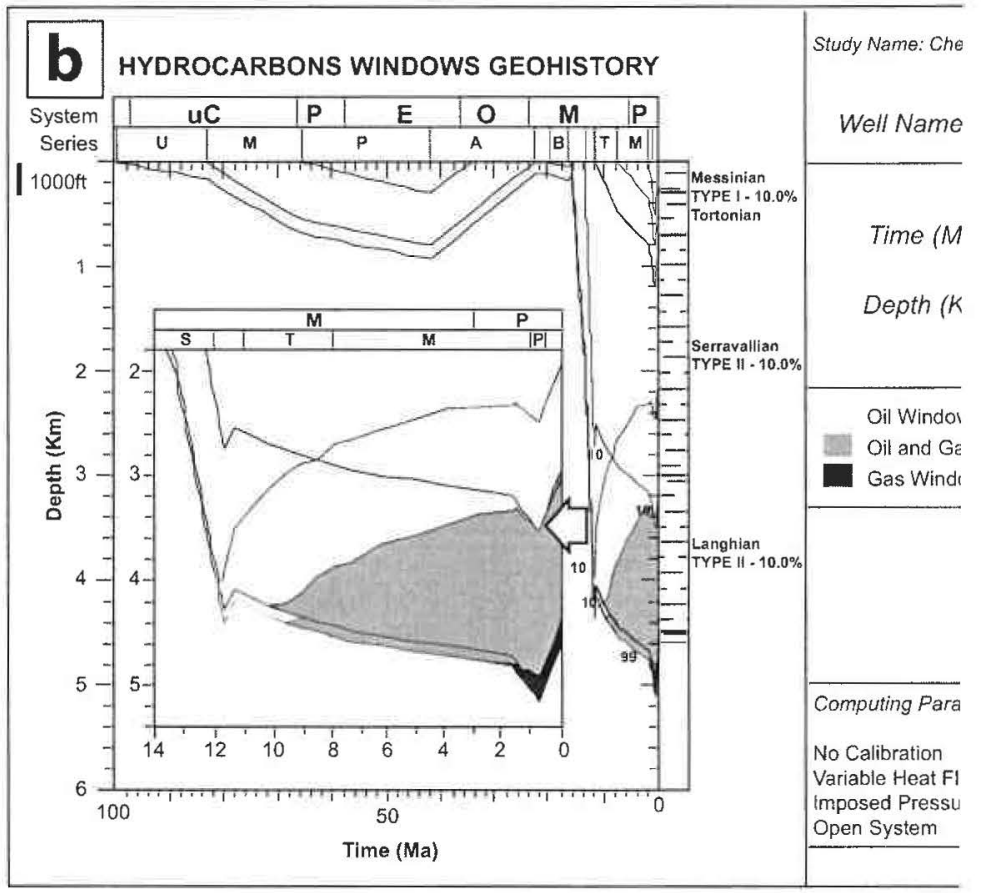

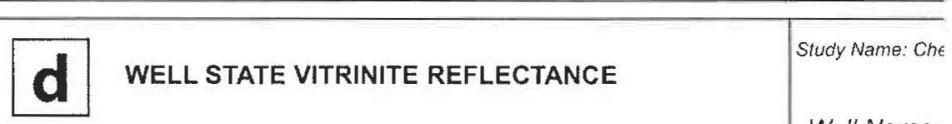

Well Name:

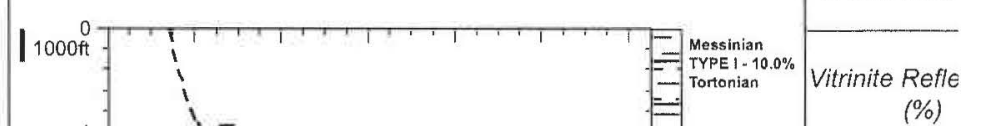

Depth (k

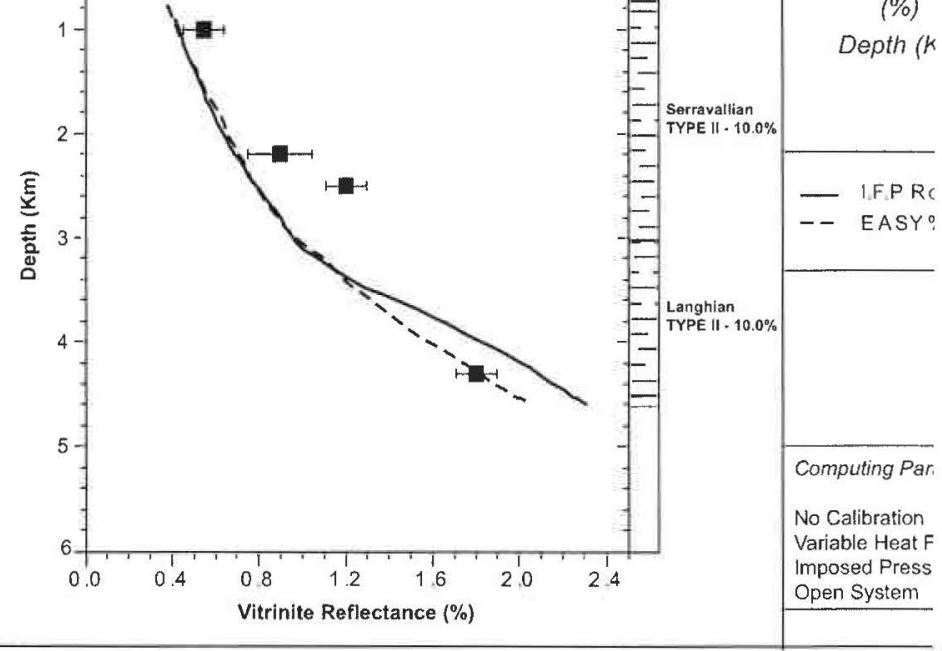




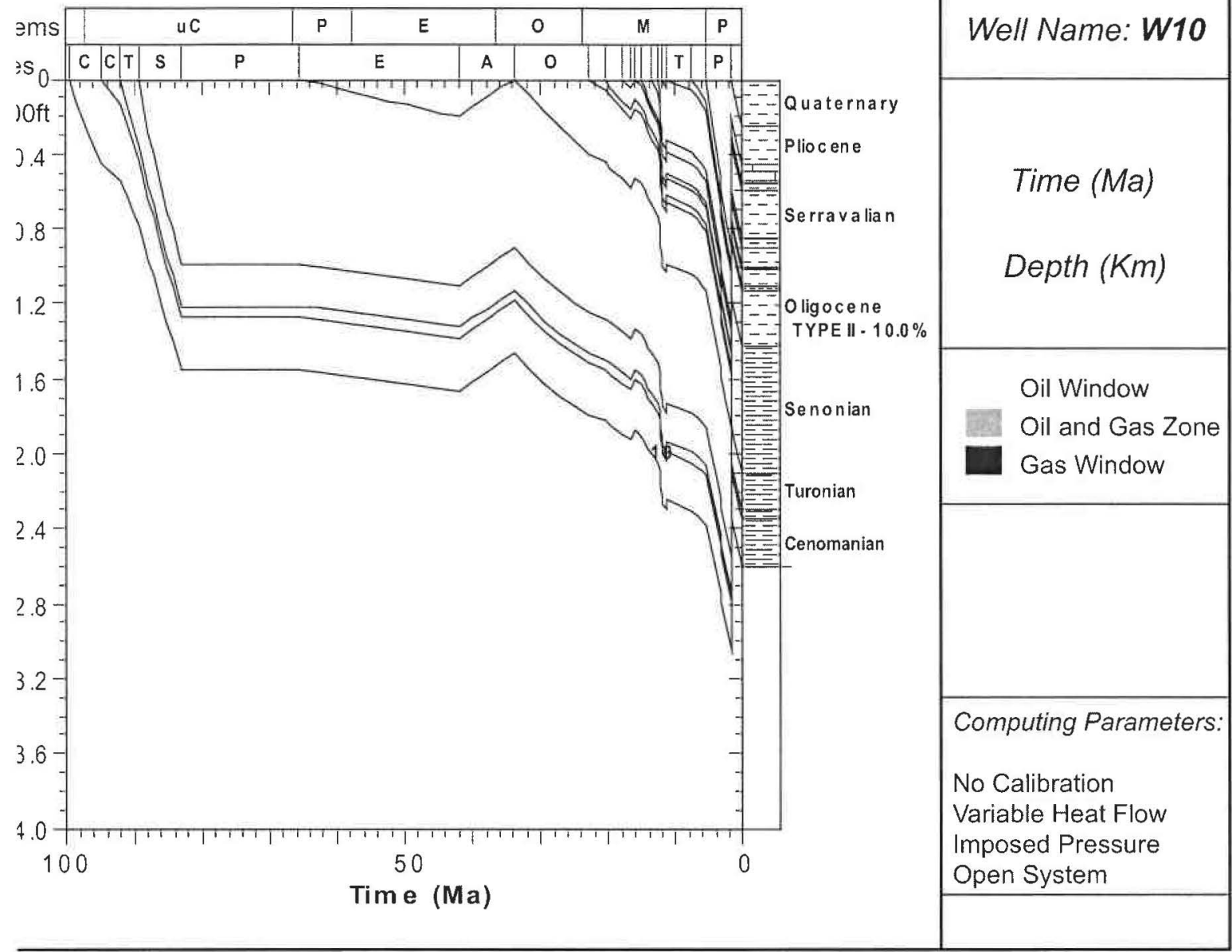

b

EXPELLED HC PER TIME INTERVAL

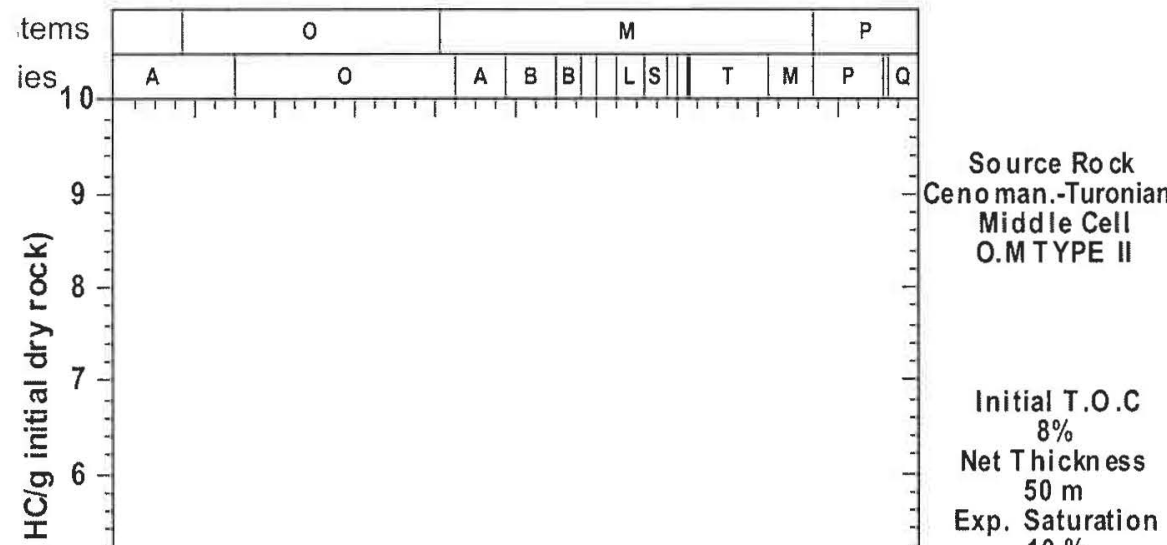

Well Name: W10

Study Name: Cheliff Basin

g)

Exp. Satu

Time (Ma)

Expelled

Hydrocarbons

( $m g \mathrm{HC} / \mathrm{g}$

initial dry rock)

Net Thickness

Gas

C6+

Computing Parameters

No Calibration

Variable Heat Flow Imposed Pressure Open System 
